\title{
Industrial life cycle: relevance of national markets in the development of new industries for energy technologies - the case of wind energy
}

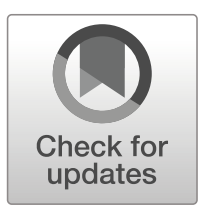

\section{Marlene O'Sullivan ${ }^{1}$}

Published online: 14 May 2020

(C) The Author(s) 2020

\begin{abstract}
About 20 years ago Klepper (1997) has shown that the life cycle theory, initially introduced for products, can also be applied to the development of industries. The industries that were examined to establish this theory were marked by relatively stable market conditions that are typically driven by innovation. However, research on the transition of the energy system has shown that markets for new energy technologies are driven by political support. As yet an analysis of the industry life cycle of an industry which has developed under politically driven market conditions has not been conducted. Therefore this paper examines the development of the global wind energy industry and the relevance of national markets in a globalized world. The study is founded on a large empirical database. A comparative analysis of various international and national developments was conducted using descriptive statistical methods. The findings show that the global development derives from the sum of individual national developments. It reveals a strong influence of national markets on the development of their respective wind energy industry. Therefore these findings provide relevant insides for the political debate on market support mechanisms in wind energy.
\end{abstract}

Keywords Industry life cycle · Wind energy industry · Relevance of national markets · Market development · Political support instruments · Market concentration

JEL codes $\mathrm{O} 33 \cdot \mathrm{O} 57$

\section{Introduction}

In order to meet the goals of the Paris climate agreement (United Nations 2015), the energy sector in every country has to make a transition towards an energy system with a

Marlene O'Sullivan

marlene.osullivan@dlr.de; http://www.dlr.de

1 Department of Energy Systems Analysis, Institute of Engineering Thermodynamics, German Aerospace Center (DLR), Pfaffenwaldring 38-40, 70569 Stuttgart, Germany 
predominant use of renewable energy sources (RES) within the coming decades (see also Teske 2019). The transition raises many questions which have to be addressed in order to help overcome the uncertainties that stand in the way of the change process. One of those uncertainties concerns the macroeconomic opportunities and risks associated with the energy transition. It raises the question which companies will provide the technology and which countries will benefit from it. To add to this debate this paper will analyze the development of the global wind energy industry. Its aim is to provide insights into the industrial development of this sector and its drivers for the discussion on the design of framework conditions.

The main theory that this paper will refer to is the industry life cycle theory (ILC) (Klepper 1997). It has been used for the empirical analysis of the development of various industries producing capital goods as well as consumer goods (see also Gort and Klepper 1982, Klepper 1996, Agarwal et al. 2002, Giachetti and Marchi 2010) and services (Menhart et al. 2004). The hypothesis that motivates the work on this paper is that the ILC of the wind energy industry might differ to the industries analyzed so far as its market creation and development have been strongly dependent on political support instruments and have therefore not been driven by innovation alone (see chapter 2). Changes in support policies for wind energy technologies due to varying political interests led to expansion paths that were unstable beyond what can be expected for capital goods markets.

Therefore, the main research question that this paper wants to address is if the development of an industry that is marked by instability in demand on national level differs to the characteristics described by Klepper (1997) in the ILC. Since this question is quite complex, it can be divided into two aspects. The first one addresses the geographic delineation, which leads to the question whether the national or the global market development was more relevant for the evolution of the wind energy industry. The other aspect is the relevance of support policies in the development of the wind industry. It raises the question if RES policies have had a significant impact on the development of the wind industry through their impact on the market development.

Looking at the evolution of wind energy for the production of electricity three different development paths can be observed. One is the utilization of small wind turbines for self-supply; another is the use of onshore wind energy with the priority to feed the electricity into the grid, and the third is the utilization of offshore wind energy. Historically the use of onshore wind for the grid has evolved from the strand of selfsupply turbines. However, in the last few years a new line of turbine manufacturers has evolved which focuses on wind turbines for self-supply. Regarding the offshore wind development a similar picture can be drawn. New manufacturers appeared with the utilization of wind energy offshore alongside large incumbent onshore wind companies. The relevance of existing manufacturers in the offshore market strongly differs to the one onshore. Therefore this paper follows the view that the development of wind energy technology should be considered as the evolution of three different trajectories (Dosi 1982). The analysis in this paper will focus on the strand of onshore wind energy for the grid but will also give some insights into the offshore development.

Chapter 2 will give an introduction of the relevant theories and findings for this paper. Chapter 3 introduces the empirical data and methodology used in this paper and assesses their relevance. The results of the data analysis are presented in chapter 4 . In the final chapter conclusions will be drawn and the need for further research will be indicated. 


\section{Theoretical foundations}

The theory of industry life cycles (ILC) is derived from the concept of product life cycles (PLC) that was developed over time by a number of authors (see among others Levitt 1965, Vernon 1966). The PLC theory describes the general development of certain performance indicators of a product over its life time such as the development of turnover, profit rate as well as imports and exports. This development is typically divided and described in four phases - introduction, growth, maturity and degeneration (Levitt 1965). During the use and development of the PLC theory, certain analogies on the development of the respective industries were drawn by a number of authors (see also Wiliamson 1975; Abernathy and Utterback 1978; Clark 1985; Klepper and Graddy 1990; Jovanovic and MacDonald 1994). However, the final model on ILC is attributed to the work of Klepper (1997). Three main indicators are subject to the ILC model - the creation of technological innovation, market development, and the number of companies active in the market (see Fig. 1). Just as in the PLC theory the development of these indicators is specified in phases of industrial development. In the case of ILC there are mostly three stages that are taken into consideration neglecting the last phase, the decline of the market as described in the PLC.

Phase one refers to the early exploratory stage which is characterized by a low market volume, uncertainty regarding the technological specification required by the market, simple product design and hardly any automatization in the production process. In anticipation of future market potentials companies enter the market with different technological concepts and the volatility of market shares is high.

Phase two is specified as a growth phase with a large market expansion rate in which the dominant design emerges. As a result the number of product innovations decreases whereas process innovations and along with them automatization of the production increases (Abernathy and Utterback 1975). The number of new market entrants decreases and shake outs can be witnessed as certain technological strands have proven to be unviable.

Phase three marks the stage of maturity. Market growth slows down, innovations are less relevant and the number of companies decreases while market shares stabilize. Company shake outs that can be seen in this phase are not only driven by the inferiority

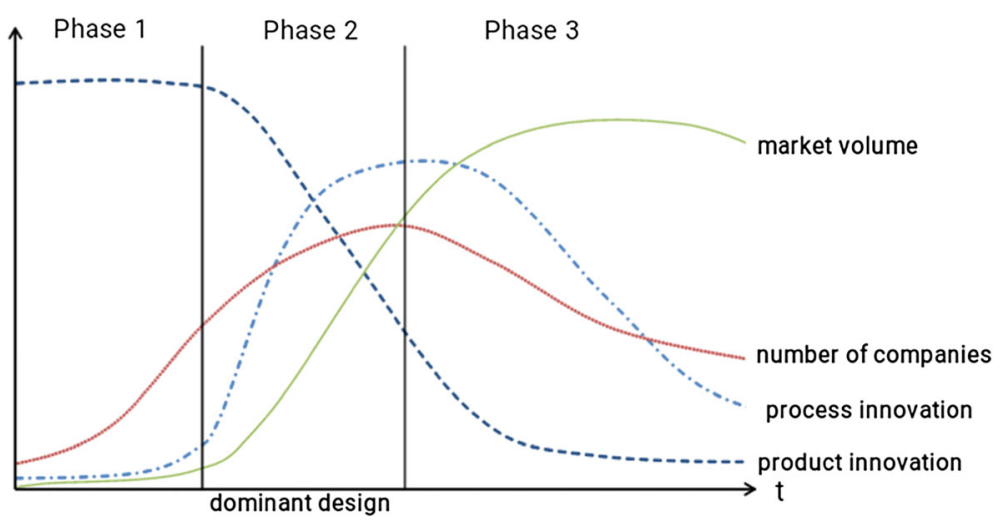

Fig. 1 Development of indicators in an industry life cycle (ILC), based on Klepper 1997 
of technological solutions but by consolidation to increase economic efficiency. Also results of various industry studies suggest first mover advantages with longer survival rates of early market participants (see also Klepper 2002).

Phase four, the decline of the market that is described in product life cycles so far does not play a significant role in the industry life cycle theory. One reason might be that industries that were subject to the ILC theory so far had not reached this stage. Also the decline of the market for an industry does not happen as quickly as it does for a product. Technologies as well as industries consist of a number of products. Their development could therefore be described as the sum of different product life cycles (Ford and Ryan 1981; Menhart et al. 2004). Therefore their development will only enter the phase of decline if a technology becomes dispensable for the market.

Klepper (1997) ILC theory has been established by the analysis of different industries in the US. However it does not seem to be clear which geographical boundaries have to be applied for the analysis of industries in the globalized world of today for the theory to be viable. As the ILC model has been derived from the PLC theory the international perspective and its findings in this strain of research will be taken into account.

The main findings regarding the international perspective of the PLC theory goes back to Vernon $(1966,1979)$. His work suggests that the production shifts over time from the country of origin - which is expected to be a developed country - to less developed countries with cost advantages. During the first phase of the PLC the advantages of the country of origin seem to be especially relevant. The theory of lead markets which was introduced much later does pick up on this aspect and widens the perspective from the higher quality of production in developed countries to the competitive advantages which are subject to such a market (see Beise 2004; Porter 1990). During the growth phase other developed countries start to produce the technology introduced by the lead market. Cost advantages become crucial in the maturation phase which leads to the shift of production to less developed countries. Another theory that will be addressed in the course of this paper is the theory of catch-up cycles. It answers the question why it is possible for latecomer countries and firms to eventually take over the industrial leadership from incumbent companies (Lee and Malerba 2017).

Regarding the development of innovations Klepper (1997) refers to the concept introduced by Abernathy and Utterback (1975). The concept that follows the interdependency of product and process innovation in the course of the life cycle still holds true today with the restriction that it is applicable for mass products and commodities. Another concept sheds light on the development of innovations in complex products and systems (Davies 1997). This concept suggests that product innovations may maintain their importance over the product life cycle. According to this theory a complex product is characterized by a composition of defined components. The equivalent of the dominant design of a product is reached once the dominant architecture of such a product has emerged. In the course of the product life cycle product innovations take place in different components. The innovation focus therefore shifts between components over time whereas the general architecture of the complex product remains stable.

Resent research on patent publications for wind energy suggests that the creation of innovation in wind energy technology follows the characteristics of a complex product 
(Huenteler et al. 2016). The dominant architecture known as the Danish Design was established in the late 1980s. Up to that point different architectural concepts had been seen regarding the philosophy of tower construction (light vs. sturdy) number of blades $(2-4)$, the orientation (horizontal vs. vertical) and the position of the rotor (upwind vs. downwind). In the end the Danish Design won the upper hand as it turned out to be the most reliable. It consists of a three bladed upwind rotor, on a horizontal axis with a sturdy tower construction (Gipe 1995; Douthwaite 2002; Maegaard et al. 2013). Even today these fundamental features are still used in nearly all wind turbines installed globally. The only component that varies depending on the manufacturer is the design of the gearbox or even the use of a gearbox at all. Innovative activity in wind turbines since the establishment of the dominant architecture has almost solely been seen in the improvement of the various components (Huenteler et al. 2016).

Coming back to the question of the relevant geographical boundaries for the ILC theory, the findings on innovation activities in wind turbines suggest that the creation of innovation in the wind energy sector is subject to a global knowledge base. This could indicate that the global perspective is predominantly relevant for the ILC of the wind industry. However a detailed analysis of market development as well as the number of companies active in the market in the context of ILC has yet to be carried out.

The formation of a market demand for new energy technologies in the course of the energy transition towards a more sustainable energy supply is subject to extensive literature. Various lock-in effects lead to inertia in the transformation of the energy system that is difficult to overcome (Unruh 2000; Seto et al. 2016). The most important one is known as the technological lock-in effect. It implies the fact that new energy technologies do not necessarily provide any new or advanced services to the consumers. Therefore a new market demand for new energy technologies cannot be created by innovation alone as implied in the technology push theory that the ILC is based on. At the same time new energy technologies are not fit to compete with incumbent technologies as they have not reached their optimal technological or economic performance at the beginning of their life cycle (Menanteau et al. 2003). The advantage of a more sustainable energy production does not create any individual economic value in itself as the external effects of incumbent energy technologies are not internalized in the energy market. This aspect in combination with increasing returns for existing technologies, form the core of path dependence. In order to overcome this inertia, political support is of essence first to provide a technological development via technology-push instruments and later to create market demand by using market-pull instruments (see also Dosi 1982; Grubb 2004; Bürer and Wüstenhagen 2009; Nemet 2009; Groba and Breitschopf 2013). As political support is strongly influenced by technological lock-in effects, institutional lock-in has been identified as an effect on its own (Seto et al. 2016). Institutional lock-in effects can result in two outcomes; they either lead to a continuation of the existing path dependence or to constantly changing political support. The relevance of political support instruments for the creation of RES markets has been identified by a number of studies (see also Kranzl et al. 2006, Kildegaard 2008, Lund 2009, Bergek and Jacobsson 2010, Haas et al. 2011, Klessmann et al. 2011, Lehmann et al. 2012, Batlle 2012, White et al. 2013, Jacobs 2014, Darmani et al. 2014). The results of these studies show that the effectiveness to create market demand of support policies depends on two main factors; the stability of policies as well as the type and level of support. 
Based on these findings the work in this paper assumes that wind energy markets were largely driven by political support systems. Therefore, the terms stable or unstable market developments or conditions used in this paper directly refer to the stability of political support in these markets. Fluctuations between individual years that lie in the nature of capital goods markets are not regarded as unstable market developments.

Another strand of innovation literature does seem to be applicable to the subject addressed in this paper. The theory on technological innovation systems (TIS) has the motivation to better understand the dynamics underlying a technological innovation (see also Carlsson and Stankiewicz 1991; Carlsson et al. 2002; Jacobsson and Bergek 2006; Hekkert et al. 2007; Bergek et al. 2008). It is widely used in the context of sustainable transitions (Markard et al. 2012) and has been applied to analyze the development of the wind energy sector in various countries or regions (see also Jacobsson and Johnson 2000; Bergek and Jacobsson 2003; Negro et al. 2012; Wieczorek et al. 2013; Darmani et al. 2014; Bento and Fontes 2015). The geographic delineation of the concept of innovation systems is not clearly addressed and subject to many discussions (Markard et al. 2015). Therefore variations of innovation systems have emerged next to TIS over time like national innovation systems (Lundvall 1992; Freeman 1995; Lundvall et al. 2002) or global innovation systems (Binz and Truffer 2017). Although there is no clear cut definition on the theory of innovation systems, there are some features that are widely accepted. Innovation systems generally consist of three elements that are intertwined with each other - actors, networks and institutions (Carlsson and Stankiewicz 1991; Jacobsson and Johnson 2000). These elements all play a role in the key system functions that have to be fulfilled in order for an innovation system to be successful. These functions slightly differ depending on the author. Seven functions that currently seem to be the essence of the development in literature are (1) entrepreneurial activities, (2) knowledge development, (3) knowledge diffusion through networks, (4) guidance of the search, (5) market formation, (6) resource mobilization, and (7) creation of legitimacy (see also Jacobsson and Bergek 2006; Hekkert et al. 2007; Bergek et al. 2008). However, the analytical framework of the TIS is not directly used in this paper as the concept in itself does not describe distinct indicators or their development over time. There are quite some publications that have applied the TIS over time (see also Bergek and Jacobsson 2003; Dewald and Truffer 2011). However, the concept that is used for the aspect of evolution is mostly the ILC with its classification of the development in phases. The TIS approach is used to explain the importance of each function in the various stages of the development. As this paper wants to look at the possible interaction between market development and the number of companies that evolve around it, the ILC theory will be in the focus of this study. However, aspects of the TIS framework are taken into consideration in the description of national developments and the interpretation of the findings.

\section{Empirical data and methods}

Energy security especially the supply of electricity is an area that receives a lot of attention from politics as well as the public. Therefore it is a sector that is relatively well monitored with a sound statistical basis. As the diffusion of renewable energies especially in the electricity sector was strongly dependent on political support in the 
past, data on the actual development was crucial to the monitoring of support instruments. The empirical basis regarding these technologies, therefore, may be even better than for conventional energy technologies. Of all renewable energies wind energy is the one with the best database in many respects.

There are a number of sources that can be used to grasp the development of wind energy globally as well as in various countries. First of all, national official energy statistics provide information regarding the wind energy production in each country. This data is collected and published by the International Energy Agency and dates back to the 1970s (IEA 2017). Secondly various governmental institutions, research institutes and industry associations gather information regarding the development of capacity expansion on national and international levels. This data has different backgrounds depending on each country. Some are derived from lists of installations such as in Denmark, others are an estimate based on data provided by market participants. The time period covered by most of these sources does not go back as far as the beginning of wind utilization in each country. Most sources provide information as of the year 2000 or later. Primarily data on cumulative wind energy capacities can be found. However, the market development can only be described by data on the newly installed capacities in each year. The source with the best information on newly installed capacities on a number of national markets as well as the global market is the Global Wind Energy Council (GWEC 2018). The period that covers global newly installed capacities goes back to 1995. National figures are available as of 2006. However, most national developments can be complemented by figures from national data sources. The global development before 1995 can be complemented by data gathered from the Earth Policy Institute as of 1981 (EPI 2018). If no information regarding the newly installed capacity is available, the development will be estimated on the basis of the cumulative development. The International Renewable Energy Agency provides such a timeline for global as well as national developments as of the year 2000 (IRENA 2018). BP provides a similar database from their statistical review of world energy that goes back to 1997 (BP 2018). The information on the diffusion of wind energy will be used for two purposes. Firstly, the data on newly installed capacities will be used as input regarding the market development of wind energy. Secondly, the cumulative capacity as well as the share of wind energy in the total energy demand will be used to select a number of countries that will be analyzed in more detail.

A first rough assessment of the development of the use of wind energy shows that three world regions have seen a considerable expansion in wind energy. Europe has been the most important world region in onshore as well as offshore development followed by Asia which took the lead in cumulative wind capacity on land in 2014. North America has played an important role in onshore development from the beginning. However, the first offshore installations have just emerged in the last few years. Regarding the development of onshore wind energy South America needs to be taken into consideration as a fourth world region. So far no offshore development has been seen here (see Fig. 2).

Regarding the choice of countries that will be presented in this paper 12 countries $^{1}$ were selected that played an outstanding role in the global wind market so far. First of

\footnotetext{
${ }^{1}$ The work underlying this paper has analyzed the development of 24 countries. Some of the findings from the other countries will be referred to in the conclusions.
} 


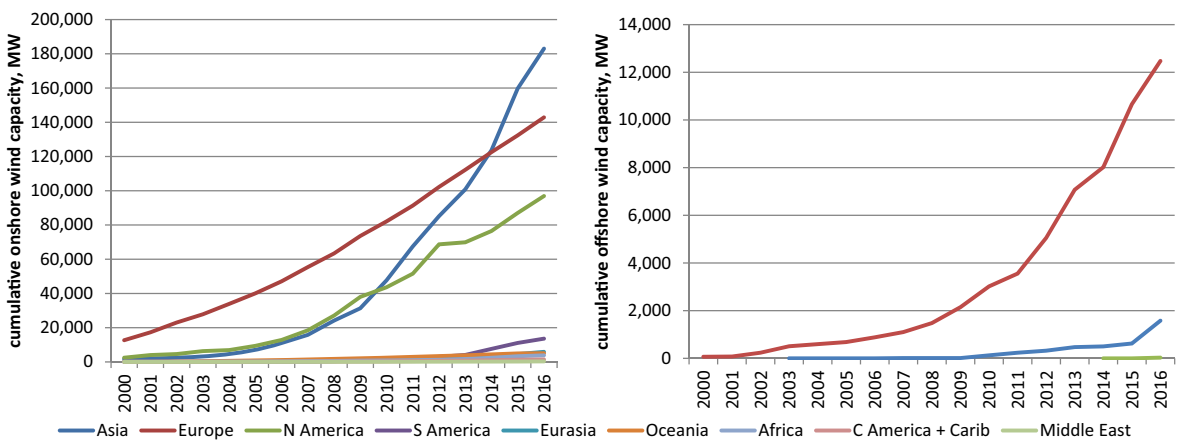

Fig. 2 Development of cumulative wind capacities in different world regions (left onshore, right offshore), MW (IRENA 2018)

all the cumulative installed capacity at the end of 2016 was used to select the nine leading countries regarding capacity expansion - China, USA, Germany, India, Spain, UK, Canada, France and Brazil. As some countries are smaller than others, the installed capacity in itself is not the only factor that displays the importance of wind energy in a market. Therefore the three leading countries regarding the share of wind energy in total energy demand -Denmark, Ireland and Portugal - were added to the table of global champions (see Table 1).

In order to gain a first impression on the individual developments of these countries the year was added in which one GW of cumulated installed capacity was achieved. The true starting point of the expansion of wind capacities is hard to pinpoint with some of these countries as official statistics do not date back that far.

As a last addition the top 10 global wind turbine manufacturers were added to Table 1. Even though most of these companies have branches in different countries they were assigned to the country where their headquarters are based. Three companies each are located in China and Germany, whereas Denmark, the US, Spain and India are home to one of the global top 10. A more detailed analysis of these companies will be conducted later in this paper. Also the analysis of individual countries in chapter 4 will start with the six countries that these companies originate in.

Regarding the development of the number of companies active in the wind energy sector over time there are a number data sources that can be taken into consideration. The most detailed and extensive one is a global database that provides information on individual wind farms. This database also includes information on the wind turbine manufacturer (The Wind Power 2018). As the data is based on hard facts and no estimations are being made regarding missing information, the market is not fully covered by this source. However, its advantage is the information it provides on all countries around the world. In order to get an impression on the coverage of the information represented in the database two comparisons will be conducted. One refers to the newly installed capacity covered in this database, the other one to the number of companies.

The newly installed capacities that are represented in the windfarm database are taken into relation to the development of newly installed capacities provided by other statistical sources (see above and Fig. 4 a)). Overall about $69 \%$ of the global capacity stated in these sources is represented in the wind farm database and $60 \%$ are linked to a turbine manufacturer. Regarding the market coverage in different countries quite a large 


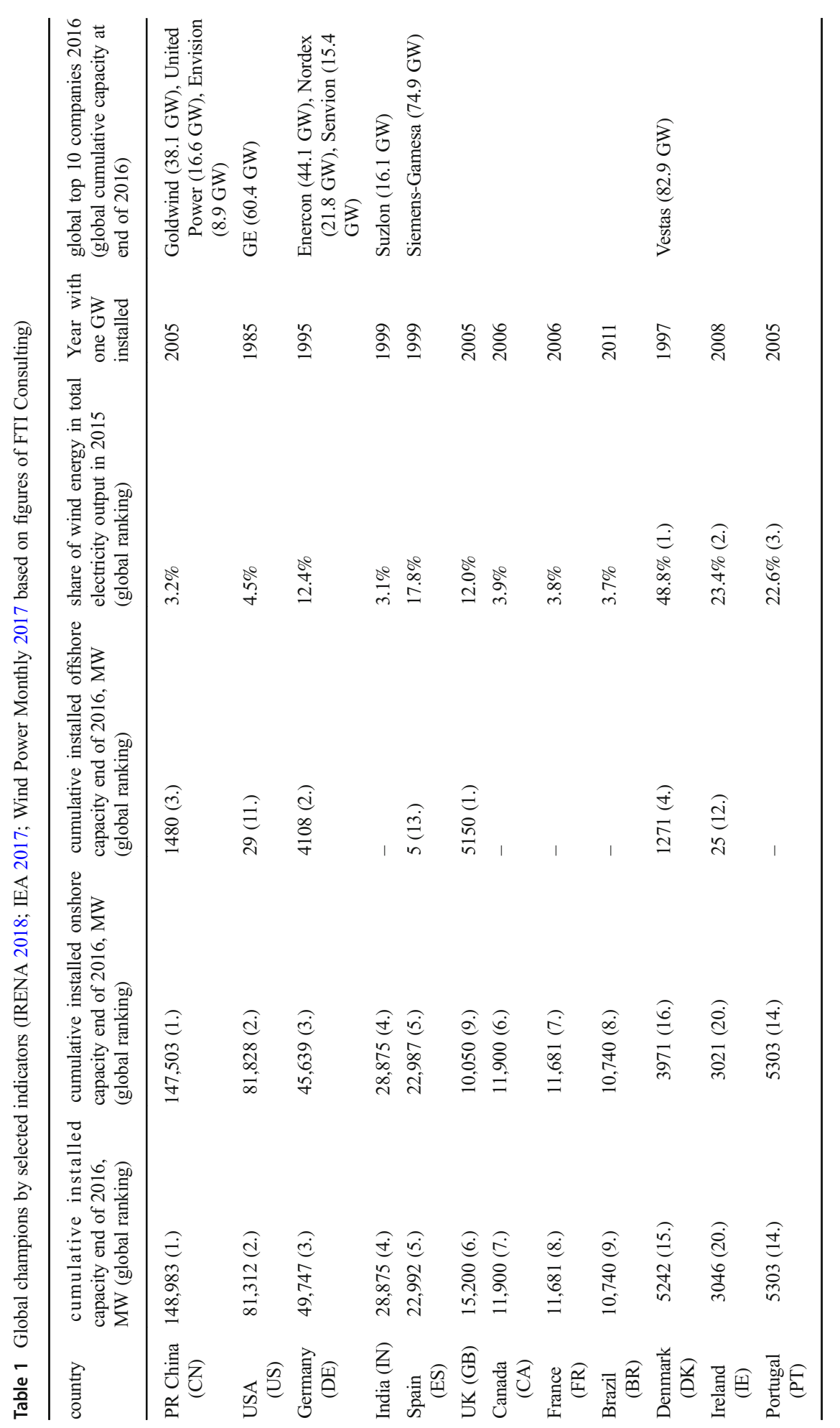


difference can be seen. For the US the coverage equals $100 \%$ of the development referred to by other statistical sources. Denmark has coverage of $98 \%$, Germany $53 \%$ and China reaches $28 \%$ of installed capacities that include company names. At the same time, the coverage varies between years. On the global level the market coverage of data including turbine manufacturers in a year is $42 \%$ with a maximum of $74 \%$ and a minimum of $0 \%$ in the early days of the development (1977-1991). On a national level, coverage of individual years differs with values exceeding $100 \%$ of the market stated in other statistical sources. What becomes apparent is a general problem of statistics in wind energy. Statistical sources often differ in the approach at which point in time new installations are taken into account. Some databases refer to the time when the turbine is finally erected; others consider the date of the connection to the grid. When it comes to windfarms, this problem becomes even more relevant. Wind farms can be built over time with each erected turbine counting in its year of installation, they can be considered when the farm is finally installed, or the connection to the grid can be taken as relevant. In order to reduce this problem the analysis of the development of different indicators from different sources will be conducted by using the centered moving average method over three years. Besides the advantage that this method might provide to reduce the difference in the accounting of different statistical sources, small short term fluctuations can be eliminated which puts the focus of the analysis to the long term cycles in the time series.

In order to test the relevance of the windfarm database regarding the number of companies involved in a market, various sources are taken into account that provide information on company market shares in several markets. On a global level Navigant Research (formerly BTM Research) has the longest history in this area with data going back as far as 1994. On national levels data could be collected for four relevant markets - Denmark, the US, Germany and China - provided by governmental energy agencies (Danish Energy Agency 2017), research institutes (Berkley LAB 2017; DEWI 2017) as well as industry associations (CWEA 2017). The only source that provides information on the full wind energy market ever since its creation is the Danish Energy Agency that keeps a register of all wind turbines built in Denmark. All other sources cover a share of the total market and do not include the beginning of the market development. They provide information on the market shares of leading wind turbine manufacturers on each respective market. It can be assumed that the share of each manufacturer is collected on the basis of the companies' statements regarding their sales in the respective market and year. The market shares can be determined by putting this information in relation to the assumed market volume. This approach differs completely from the approach seen in the windfarm database that has individual wind farms in focus $^{2}$ with the information on the manufacturer being secondary. Therefore it seems to be possible that the wind farm data base can provide information on more companies than the sources on the US, German and Chinese markets even though it may cover a smaller market share (see Fig. 3).

As only the Danish registry of wind turbines provides data on the whole market the question needs to be answered whether an incomplete market representation can provide information on the development of the number of companies. An analysis of the Danish data in Fig. 3 shows that the general development path can be outlined by an

\footnotetext{
$\overline{2}$ This also holds true for the Danish data source.
} 

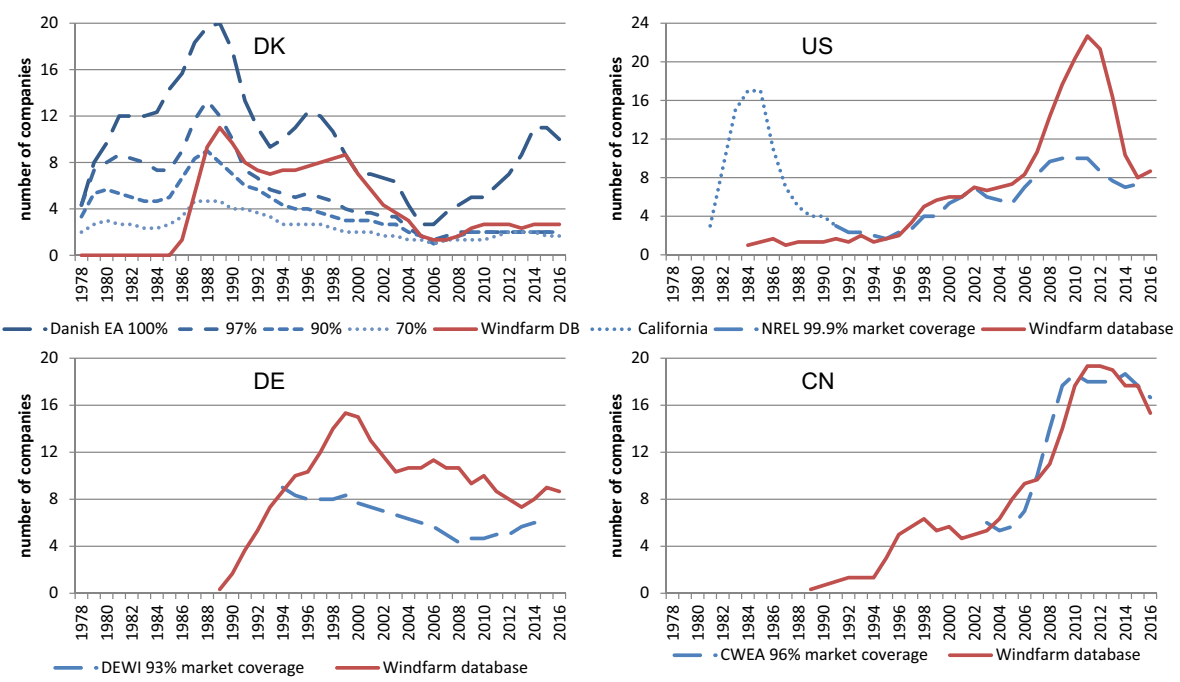

Fig. 3 Number of companies involved in the Danish (DK), US, German (DE) and Chinese (CN) wind turbine market, moving average over three years (own representation based on The Wind Power 2018, Danish Energy Agency 2017, Jaeger 2013, Berkley LAB 2017, DEWI 2017, CWEA 2017)

incomplete market presentation. However, the development that cannot be captured with a reduction by only a small fraction of the market is the evolvement of manufacturers for small turbines for self-supply. As the data on Denmark is the only source including the windfarm database that provides any information on the development of small wind turbine manufacturers, the analysis in this paper will focus on the trajectories of onshore and offshore wind energy for the grid.

Regarding the relevance of the windfarm database for the development of the number of companies active in a market, the data was compared with the respective data from the above mentioned sources. The comparison shows that the general trends of the development of number of companies can be recreated by the windfarm database even though the relative height differs. The only time period that is not covered appropriately is prior to 1990 . However, this shortfall can be met by including the development in Denmark and California (US) that were, at that time the most relevant markets. The Danish market can be fully represented. The market coverage of the available data on California is not clear. Jaeger (2013) offers information on 21 companies in the period between 1981 and 1991 including the top 10 of three continents; 10 from the US, 10 from Europe and one from Japan. However, he also mentions that more than 30 manufacturers were active in the Californian market at that time. Nevertheless, just like the windfarm database lacks a full coverage of the market, the relevant point in this survey is the representation of the general trend.

The methods used to analyze the data presented above are exclusively derived from the field of descriptive statistics. The graphical representation of various indicators in the form of time series provides a good overview of the course of each development and allows for the identification of the different development phases. Additionally, statistical interrelations are drawn in a regression analysis for the global as well as individual national developments. They will be performed on the individual phases of the ILC as the theory indicates differences in the potential interrelations in each phase. 
In combination this allows for a comparative analysis of different developments both between individual indicators and between different countries.

\section{Results}

\subsection{Global development}

To analyze the industry life cycle of the wind energy industry the global perspective will be chosen as a starting point. As mentioned before, Huenteler et al. (2016) findings on the development of innovation in wind energy seem to indicate that the global perspective is relevant for the industrial life cycle. However, analyses of the other indicators that define the ILC theory have to be conducted first in order to be able to give a definitive statement.

For the analysis of the relevant indicators four figures were created (see Fig. 4). Each figure contains two different development paths - one for onshore wind and one for offshore wind. The first figure shows the market development as it is stated by the respective sources in order to give an impression on the magnitude of the evolution (see Fig. 4 a). The second shows the same data in a logarithmic representation with the difference that short term fluctuations are reduced by applying the centered moving average method over three years (see Fig. 4 b). The third figure represents the development of the number of companies also using the moving average method (see Fig. 4 c). And the last one shows the development of the market concentration
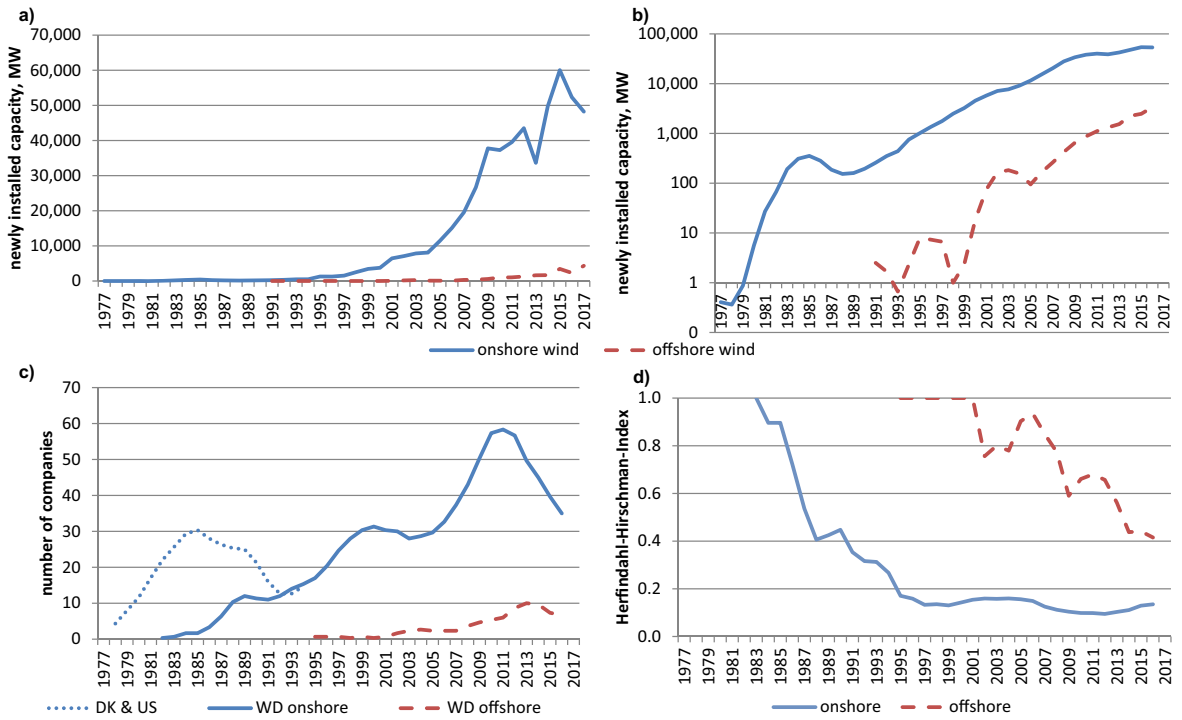

Fig. 4 a Development of newly installed capacity (own representation based on GWEC 2018, EPI 2018, Danish Energy Agency 2017), b Logarithmic representation of the development of newly installed capacity, moving average (see Fig. 4 a) c Development of number of companies on the global wind market, moving average (own representation based on The Wind Power 2018, Danish Energy Agency 2017, Jaeger 2013, Berkley LAB 2017), d Market concentration on the global wind market, moving average (own representation based on The Wind Power 2018) 
by using the moving average of the Herfindahl-Hirschman-Index (see Fig. 4 d). The onshore development will be analyzed first, followed by the offshore development.

The first thing that becomes apparent when looking at Fig. 4 a) is that the expansion of onshore wind energy covers the major share of the overall global wind energy development with 453 GW cumulative installed capacity in 2016 (IRENA 2018). The market evolution on land started in the aftermath of the international oil crisis in the mid-1970s. Import dependency became an urgent issue with regard to security of energy supply which led to the search for alternative domestic energy sources. The first market demand for onshore wind energy was created in 1977 in Denmark followed by California. The early years of the global development are easier to see in the logarithmic representation (see Fig. 4 b). It shows the short but strong expansion of wind energy in the phase of the Californian market in the first half of the 80 s that ended with a market collapse in which the yearly installed capacity was reduced by almost $70 \%$ within 3 years. The global market development picked up again around 1990 with an exponential growth that could be observed until 2009, followed by a deceleration of market growth that indicates the beginning of a saturation phase. At the moment it is not yet possible to predict whether the current expansion is at a sustainable level and development will stabilize or if a decline to a lower level is to be expected in the coming years. Theoretically, it can be expected that at some point a stable expansion level should be reached. Even when the energy transition will be completed, the turbines will need to be replaced at specified intervals that are currently assumed to be every 20 years.

The two cycles which are indicated by the onshore wind market development can be further divided when looking at the evolution of the companies' active in the market (see Fig. 4 c). The data suggests that three cycles might have occurred so far. The first one from the beginning of the deployment until the early 90 s with a certain amount of time lag compared to the market development. The second cycle with its peak around the year 2000 lasted until 2003 and was followed by the third wave of new companies which had its peak in 2011. It remains to be seen whether the decline in the number of companies in recent years will mark the beginning of a final phase of consolidation and maturity. However, the market development indicates that this might be the case.

A regression analysis has been conducted to see if the development in the number of onshore wind manufacturers can be statistically explained by the global market development. Looking at the development of the two indicators in the ILC theory (see Fig. 1) a strong explanatory quality would be expected for the formation phase of an industry. The shake-out phase, on the other hand, is not expected to have a good coefficient of determination.

Subsequently, the statistical analysis was conducted for different time periods. The periods were chosen according to phases of growth and consolidation of the number of companies. However, this means that the regressions are carried out with a comparatively small number of observations. This must be taken into account when interpreting the results. In the case of particularly small observation numbers, a regression will be carried out to ensure completeness. The issue will be specifically pointed out in each one of these cases. The regression tables are displayed in the Annex of this paper.

The results show an adjusted $\mathrm{R}^{2}$ of 0.97 for the number of companies with the logarithmic representation of the global market development in the first formation phase of the industry between 1978 and 1985. The analysis of the second growth phase (1994-2000) also shows the best results with a logarithmic representation of the 
global market development. The adjusted $\mathrm{R}^{2}$ amounts to 0.96 . The linear regression of the third growth phase (2004-2011) shows an adjusted $\mathrm{R}^{2}$ of 0.98 . Overall, all three industry growth phases show a very high explanatory value of the global market development with a strong positive interrelation.

The three phases of consolidation that could be observed on the global level show a range of results. The first shake-out phase (1986-1993) shows an adjusted $\mathrm{R}^{2}$ of 0.49 which does indicate some interdependency but is not sufficient. The second one (20012003) does not show any explanatory value of the model. The third one (2012-2016), on the other hand, provides an adjusted $\mathrm{R}^{2}$ of 0.90 with a negative interrelation between the two indicators showing that the general market trend was positive while the number of companies was decreasing. Again, the findings of the statistical analysis have to be treated with caution as some of the periods only refer to a very small number of observations. This is especially true for the second shake-out phase.

As the appearance of a second and third cycle in the number of companies in the onshore wind market cannot be explained sufficiently by the global market development, a more detailed look into the development of companies seems necessary. Figure 5 shows the development of market shares for groups of companies from one country on the global market. The graph on the left covers the market share of onshore wind; the right one displays the offshore development. As in Table 1 companies were assigned to the country in which they have their headquarters. As the market coverage of the windfarm database differs between countries, the relative shares given in this graph have to be treated with caution. The data for the global market provided by BTM/Navigant (2017) show that the share of Chinese companies in the global onshore market was larger than indicated by Fig. 5. Especially the decreasing relevance of Chinese manufacturers in the last few years cannot be seen.

However, what this graph displays is the point of entry of companies from individual countries to the wind market. For the onshore development it shows that Danish, Japanese, US and German companies were already active in the global wind market in the beginning of the 1990s. A few years later Spanish and Indian companies followed. Finally Chinese manufacturers made their appearance onto the global onshore wind market at the beginning of the 2000s, which matches the appearance of the third wave of new companies. All in all, the data indicates a relevance of national markets, which will be examined further in chapter 4.2.

Looking at the development of the market concentration in onshore wind in Fig. 4 d, the trend seems to follow the expected path. In the initial phase in which a relatively
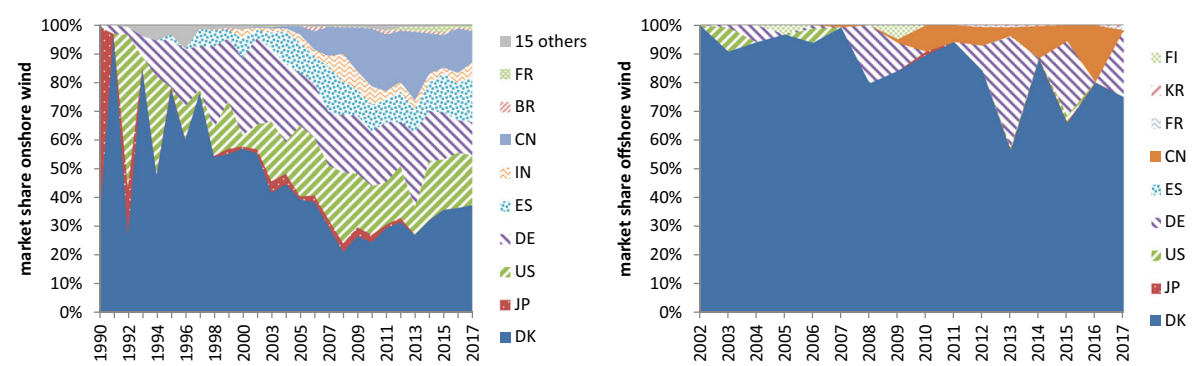

Fig. 5 Market share of companies from selected countries in the global market (own representation based on The Wind Power 2018) 
low amount of windfarms was installed in each year, market concentration was high. However, since a certain market level had been reached, competition reduced market concentration. Overall, the global onshore market appears to have been highly competitive for many years, with the result that low market concentration prevails.

The global offshore wind development is at a very different stage than the utilization of onshore wind energy with altogether $14 \mathrm{GW}$ of installed capacity in 2016 . The four largest offshore wind markets are the UK, Germany, China and Denmark covering 85\% of the global overall installed capacity. The largest cumulative installed capacity of just over $5 \mathrm{GW}$ in 2016 was located in the UK followed by Germany with just over 4 GW. China just took the third rank over Denmark in 2016 with just under $1.5 \mathrm{GW}$ of overall installed capacity (IRENA 2018). The market development of offshore wind energy started in 1991 in Denmark. The development up until today as displayed in Fig. 4 a) and $b$ ) indicates that the industry is still at an early stage of market utilization. However, the development of the number of companies seems to point to a first shake out phase (see Fig. 4 c)). It has to be stressed that this impression could be deceptive, as at this stage of the development individual projects have a great influence. The impression of the offshore market still being at an early phase is also given by the high market concentration that still exists even though the trend indicates a continuous reduction.

The right graph in Fig. 5 shows the global offshore wind market shares of companies from different countries. The strong market position of Danish wind turbine manufacturers stands out as in the early days of the onshore wind development. However, it is basically one company - Siemens - that so far has provided more than $60 \%$ of the globally installed offshore wind capacity. An analysis of the industry life cycle of individual national markets for offshore wind turbines does seem interesting. However, the size of the respective national markets in combination with the size of individual offshore windfarms makes an analysis at the current point in time difficult as the number of wind farms that are installed in one year is relatively small and varies significantly between years. Therefore the analysis of national markets will focus on the onshore wind development.

\subsection{National development}

In simple terms, global market development can be described as the sum of national market developments. The extent to which a national market development influences the global market development depends on its share and can change over time. In order to facilitate a better overview and understanding of the national markets that will be presented in this chapter some more information is provided in Table 2 that will add to the information given in Table 1.

The information provided in Table 2 shows various indicators referring to the role of each market in the global development in the past as well as the wind onshore potential. The market potential is implied by two indicators, the total power generation which shows the current power demand of each country and the technical wind power generation potential. The data on the wind electricity generation potential was taken from an internal source. Another publication from Eurec et al. (2017) shows slightly different numbers but the overall conclusion is the same. The theoretical wind onshore generation potential does not restrict market development as it is larger than the current electricity output of each one of the countries that are analyzed in this paper. 


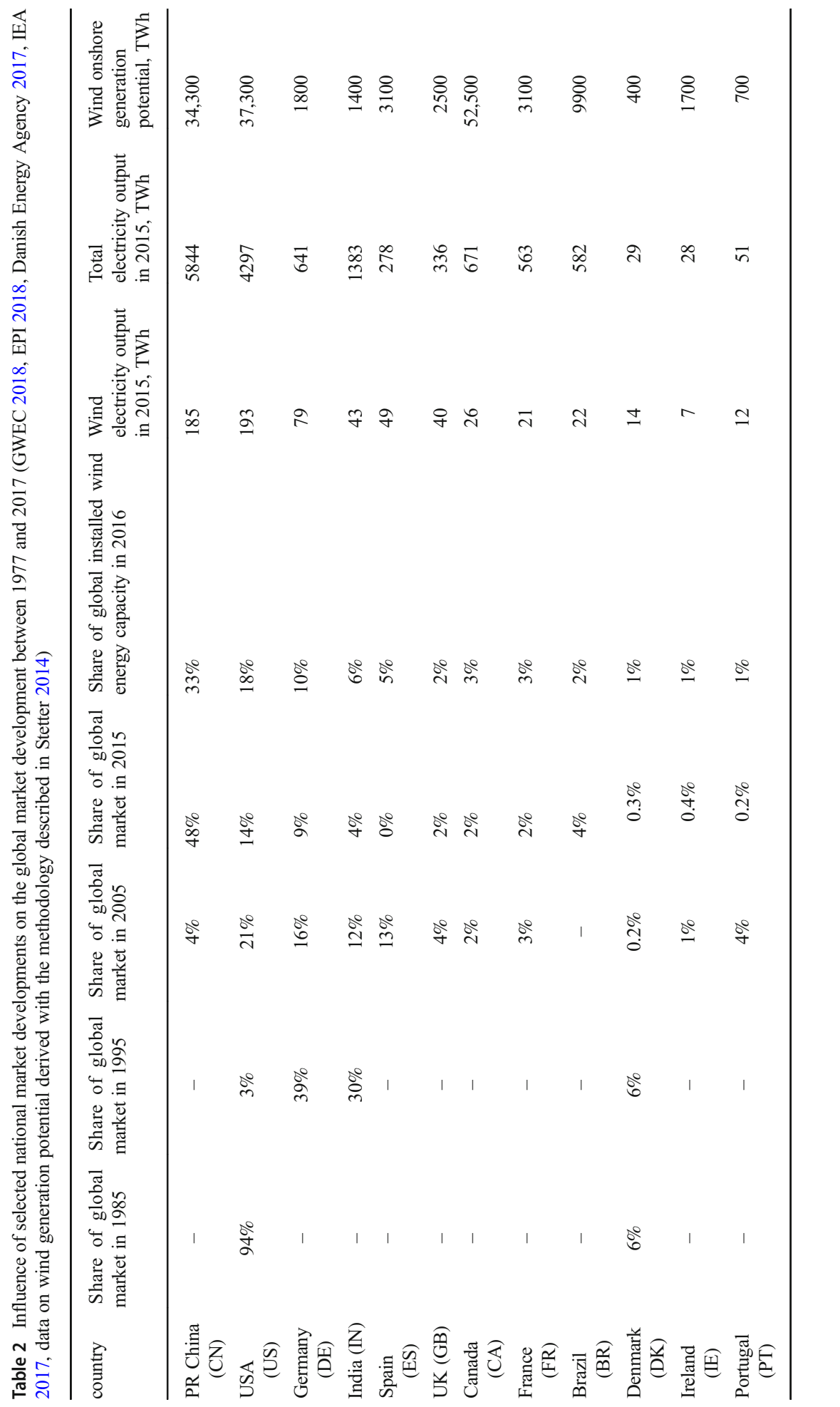


The figures on the share of national market developments in the global market in 1995 show one of the main short comings of this study. The data provided by The Wind Power (2018) does indicate that a wind energy market existed in Spain, China, UK, Canada, France, Ireland and Portugal at that time. As market data for the early development phase could only be gathered for Denmark and the US, the first phase of the ILC can only be analyzed for these two markets.

As already mentioned, the analysis of national developments will start with the six countries hosting the global top ten wind turbine manufacturers - Denmark (DK), the US, Germany (DE), India (IN), Spain (ES) and China (CN). The analysis of each one of these markets will include a short introduction to the development of political support systems that helps to explain market developments. Also a detailed analysis regarding the wind industry active in these markets will be conducted showing the role of national based companies as well as the engagement of foreign companies. To provide some insight to the dynamics in the industry itself, detailed information regarding the origins of the top 10 global wind companies will be provided.

\subsubsection{Denmark}

Denmark is often referred to as the lead market of wind energy (see also Beise and Rennings 2003). With its strong energy import dependency and very good wind conditions, it was the first country to introduce wind energy for electricity production that was fed into the grid. Even though Denmark, due to its size, only has an installed wind capacity of about $4 \mathrm{GW}$ onshore and another GW offshore, it is the leader in wind utilization and integration. In 2015 almost half of the electricity output of the country came from wind energy (see Table 1). Until today, the innovations that came from Denmark have shaped the use of wind energy. At the same time political support of the wind market has seen a lot of changes which makes Denmark one of the countries that has seen a high amount of instability in its market.

In Denmark wind energy has its roots in a community movement. After the oil crisis in 1973 farmers started to look for possibilities to generate electricity for self-consumption. They experimented with wind turbines that were simple, robust and reliable. This wind turbine design was gradually improved with experience from existing installations. This bottom up approach led to the creation of the Danish wind turbine design which turned out to be the dominant design up until today. The first players in the Danish wind energy movement managed to get governmental support for their request to be able to feed electricity into the grid as a private person or co-operative like society. Therefore regulation rules for guaranteed grid access were in place at a very early point in time. The first support system was a $30 \%$ subsidy on wind turbine investment in 1981 which started the Danish market development and ended in 1988. The first form of a feed in tariff with a guaranteed remuneration of wind energy which was fed into the grid was developed in 1990. Its level was set as a percentage of the retail electricity rate. When the effect on the market development was not as expected, a fixed feed in tariff was introduced in 1993 (IRENA 2012). Even though Denmark was the pioneer in all those regulative innovations that have marked the success of global wind energy deployment, the Danish wind market has seen a lot of changes in political support (Gipe 1995; Maegaard et al. 2013; Vestergaard et al. 2004; Douthwaite 2002; Karnoe 
and Garud 2012). The feed-in tariff system was stopped in 1999 with the introduction of renewable portfolio standards which reduced the Danish wind energy market once more. The restructuring of the energy market in 2004 was followed by the introduction of price premiums in 2009 (IRENA 2012).

Looking at the development of the national markets the effects of the history of political support can be seen (Fig. 6). Denmark currently seems to be in the third cycle since 1980 with the first cycle ending at an installation level that was more than $40 \%$ below the maximum expansion in this wave and the second one with a difference of $98 \%$. The current cycle has seen a relatively stable market development in the last few years which might indicate a currently sustainable level of expansion.

The development of the number of companies active in the Danish market is displayed in Fig. 6 on the right. The first cycle that was seen in the development of the national market was accompanied with a complementary development of market players. A regression analysis of the formation phase of the first cycle was conducted with a logarithmic representation of the national market development (see Annex). It shows that the growth in the number of companies between 1978 and 1989 can be explained by an adjusted $\mathrm{R}^{2}$ of 0.94 . A multiple regression adding the global development without the Danish market as a second independent variable increases this value to 0.96 . The regression of the national market development for the short shake out phase between 1990 and 1993 has to be treated with caution due to the very small number of observations. Consequently, the significance level of this regression is not sufficient. The explanatory quality turns out to be quite high taking the theoretic assumptions into consideration (adjusted $\mathrm{R}^{2}=0.81$ ). The coefficient of determination is not raised by taking the rest of the global market development into account, showing the influence of the national development. The start of the second cycle of market development in 1994 hardly increased the participants on the market for larger wind turbines. The peak of companies was reached in 1997 with 12 companies active in the Danish market. Again, the regression analysis of this short phase of another four years did not turn out with a relevant significance. It shows an adjusted $\mathrm{R}^{2}$ of 0.67 which is increased to 0.97 with the additional consideration of the global market. The strong decline in the national market at the end of the second cycle (1998-2006) had the consequence that the number of companies has been reduced to essentially two Danish players - Vestas and Bonus that had been taken over by Siemens at the end of the second cycle. The regression analysis of this phase shows an adjusted $\mathrm{R}^{2}$ of 0.75 with a relevant significance whereas the regression including the global market outside of
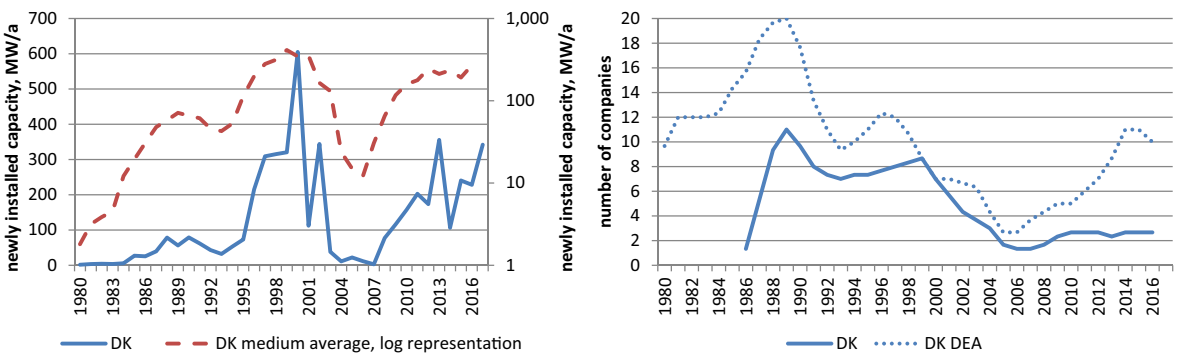

Fig. 6 left: Development of newly installed wind onshore capacity in DK (own representation based on GWEC 2018, Danish Energy Agency 2017), right: Development of number of companies in the Danish wind onshore market (own representation based on The Wind Power 2018, Danish Energy Agency 2017). 
Denmark did not produce a high enough significance. At the beginning of this shake out phase, market development was still ongoing indicating a shake out as it is expected in the ILC. However, the steep decline in market demand led to a relatively strong coefficient of determination for the development of the industry with a strong positive interrelation. The third development cycle in Denmark did not have any major effects on the number of companies active in the onshore market for grid applications at all. A detailed analysis of the data from the Danish Energy Agency (2017) shows that the increase in companies which can be seen in Fig. 6 can be traced back to the development of small wind turbines. The two major national players from the beginning of the development remained and as the size of the market in Denmark is not very big in terms of numbers no established companies from other countries emerged on the Danish market.

Even though the Danish market might be relatively small, it is home to two global champions (Table 1). The leading company Vestas has a history going back all the way to the beginning of wind utilization in Denmark. Its merger with NEG Micon, another reknown Danish wind turbine manufacturer with roots at the beginning of the Danish development, in 2004 needs to be mentioned (Maegaard et al. 2013). In 2014 Vestas has entered into a joint venture with Mitsubishi (JP) which concentrates exclusively on the offshore wind market. Vestas has production sites in 8 different countries on 4 continents and most of its turnover is generated outside of Denmark (Vestas 2018).

The wind business of the second largest Danish company Siemens ${ }^{3}$ goes back to the acquisition of Bonus in 2004, another player of the early days in Denmark. In 2017 Siemens merged with Gamesa the leading wind turbine manufacturer in Spain to form Siemens-Gamesa. The headquarters of the new company are located in Spain (Siemens Gamesa 2018). The onshore wind development will be served from Spain while the Danish locations hold the headquarters for the offshore wind business. The offshore wind technology owned by Gamesa (formerly Multibrid (DE), acquired by Alstom (FR) and brought into a joint venture with Gamesa (Adwen)) will not be continued.

\subsubsection{United States of America}

The US wind market is currently the second largest wind energy market in the world with an installed onshore wind energy capacity of $82 \mathrm{GW}$ at the end of 2016 (see Table 1). It has an enormous wind onshore generation potential of about $37 \mathrm{PWh}$ that is theoretically available to provide a significant part of the electricity output (approx. 4.3 PWh) (see Table 2). Its market development so far has seen changing political support which resulted in instability.

The US was one of the leading countries in the development of wind energy. After the first oil crisis a national research program was set up led by NASA, during which several wind turbine designs were developed. However, none of these designs coming from this top-down approach managed to get the upper hand over the reliable bottomup design of the Danish development. The national energy act of 1978 introduced the

\footnotetext{
${ }^{3}$ It might seem odd to refer to Siemens as a Danish company when the Siemens group a renowned German company. However, when it comes to wind energy Siemens remained the strong bond to the Danish market by leaving its production and headquarters in Denmark. The six year time period between 2011 and 2017 in which Siemens has eventually shifted its official headquarters to Germany has not changed much of this perspective.
} 

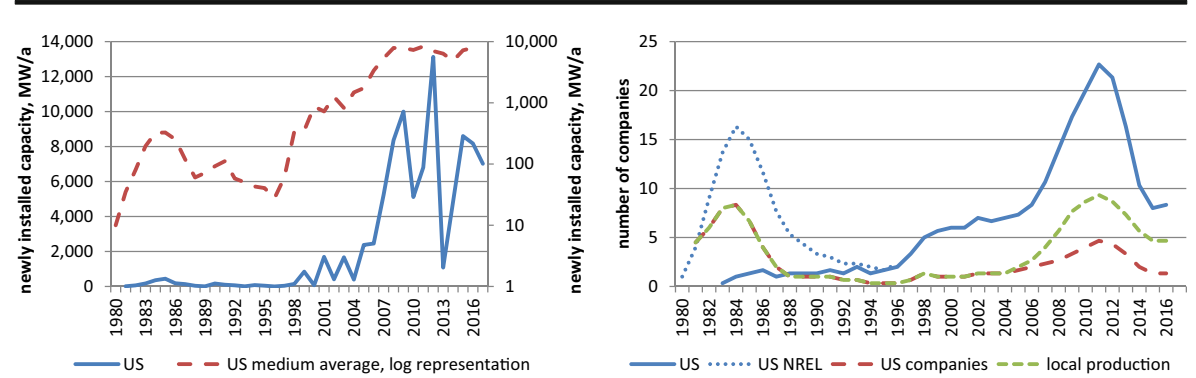

Fig. 7 left: Development of newly installed wind onshore capacity in US (own representation based on GWEC 2018, BP 2018, Berkley LAB 2017, AWEA 2018), right: Development of number of companies in the US wind onshore market; US/US NREL refer to all companies active in the US market, US companies refers to companies that are based in the US, local production refers to companies with a production site in the US (own representation based on The Wind Power 2018, Jaeger 2013, Berkley LAB 2017).

first tax credit which was not sufficient for a notable market development. California offered an additional investment tax credit in 1980 which abruptly ended in 1985. This support system has been the cause for the first market cycle in the US (Fig. 7). After the high point in 1985, the market broke down by $98 \%$ until 1989. The second wave of market development that started in 1999 has been quite unsteady as many boom and bust phases could be witnessed that were the result of the short-term nature of the political support system (IRENA 2012; Gipe 1995; Maegaard et al. 2013; Vestergaard et al. 2004; Douthwaite 2002).

The development of companies in the US market has also seen the two cycles described by the market expansion path (see Fig. 7). During the first wave, a series of national based companies emerged in the Californian market within three years. The regression analysis of the national industry development with the market development for this very short time has to be treated with caution as it did not provide enough information for the regression to be significant (see Annex). The results show an adjusted $\mathrm{R}^{2}$ of 0.90 with the logarithmic representation of the national market development. During the steep decline of the market that followed all national US companies left the market. The adjusted $\mathrm{R}^{2}$ for the period between 1985 and 1994 is 0.95 with a very high significance and a strong positive interrelation between the two declining indicators. The explanatory value of the regression analysis is not improved by the consideration of the rest of the global market. However, it can be assumed that this shake out of national based companies from the US might have happened eventually. In this period the dominant design established which was provided by Danish companies.

During the second cycle of market growth only a few new national based companies emerged. The regression for the phase between 1995 and 2011 shows a coefficient of determination of 0.88 for the US market. Taking the rest of the global market into account $\mathrm{R}^{2}$ is improved to 0.97 with a higher significance of the global market than the national development. Again, when looking at the national development in this period it becomes apparent that the market development between individual years was not very reliable. Therefore, it can be assumed that the global market had a stabilizing effect on the industry. The bulk of companies active in the second cycle of the US market seen in the graph are companies from other nations seeking the opportunity in one of the largest wind markets. Most of those companies started local production with 
the rise of the US market. It can be assumed that these decisions were primarily driven by the promises of the potential of the US wind energy market. Local production requirements were never introduced on the national level in the US. However, a number of states introduced additional incentives for companies to set up local production (OECD 2015). The regression analysis of the companies with a production in the US and the national market development shows an explanatory value of 0.94 which increases to 0.99 with the global market included.

The decline in the number of companies that was seen between 2012 and 2016 cannot be explained by the national market development. However, it does correspond to the global development in the aftermath of the financial crisis in 2009.

The one US wind company of global importance is General Electrics (GE). It is the dominant company in the US market with an average market share of $45 \%$ since 2003. GE started its engagement in wind energy technology with the acquisition of Enron (US) in 2002. Enron in turn had entered the wind market with the acquisition of Tacke (DE) and Zond (US) in 1997 which started its business in the Californian market in the early 80s. As the dominance of the Danish design became apparent Zond retreated from its own turbine production and focused on the development of wind parks in the US using Vestas turbines. In 1993 it went back to the design of its own turbines and acquired the patents of the bankrupt Kenetech (US) in 1996 (GE 2018). In the last few years GE acquired two more companies which have to be mentioned. In 2015 it took over the energy business of Alstom (FR) including all of its onshore wind activities. In 2017 GE bought LM Wind Power (DK) one of the most important wind turbine blade manufacturers that goes back to the beginning of the wind market development in Denmark.

\subsubsection{Germany}

Germany had an installed onshore wind capacity of about 46 GWh in 2016 and the share of wind energy output in the total electricity output amounted to over $12 \%$ in 2015 (see Table 1). The wind onshore generation potential in Germany amounts to 1.8 PWh and the current national electricity output is around $641 \mathrm{TWh}$ (see Table 2). The German onshore wind energy market started slightly after the Danish and US American market. In 1995 it was the largest market in the world (see Table 2). So far it can be regarded as a relatively stable market as it was driven by feed-in tariff systems throughout its development.

Germany is another country that has had a major influence on the development of wind energy technology. Just like in the US a research program was established in the mid-70s that had the goal of creating a multi-megawatt wind turbine. The "GROWIAN" was discontinued in 1987 and taken down the following year. When the challenges of large wind turbines became evident in the mid-80s the research program was opened to smaller applications. After the first demonstration projects in the 80s the "Stromeinspeisegesetz" came into effect in 1991 that complimented technology demonstration projects. This first feed-in tariff system in Germany was inspired by the Danish development and was followed by the Renewable Energy Sources Act (EEG) in 2000 with the support of all political parties (see also HoppeKillper 2003; IRENA 2012; Maegaard et al. 2013). This has led to a comparatively stable market development in Germany that seems to follow the path described by the classic ILC theory for industries under normal market conditions (see Fig. 8). 

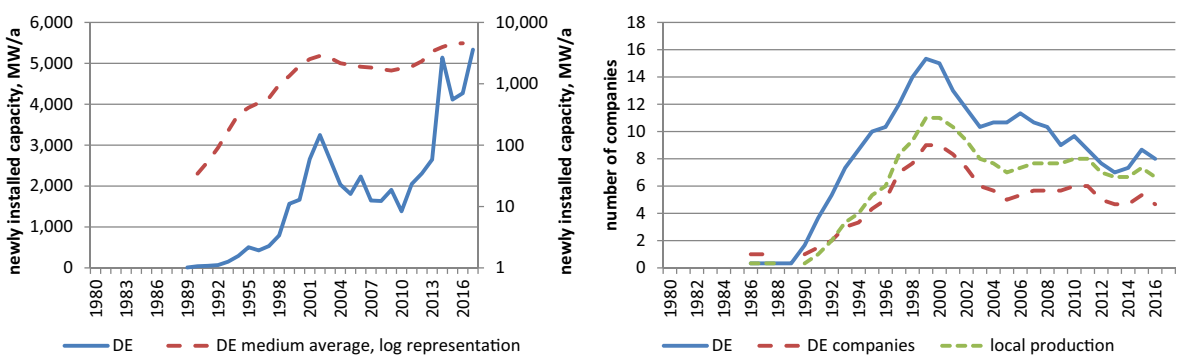

Fig. 8 left: Development of newly installed wind onshore capacity in DE (own representation based on GWEC 2018, Durstewitz et al 2001, BMWi 2018), right: Development of number of companies in the German wind onshore market; DE refers to all companies active in the German market, DE companies refers to companies that are based in Germany, local production refers to companies with a production site in Germany (own representation based on The Wind Power 2018).

After a long phase of relatively constant annual capacity expansions, there has been an increase in new installations in the last few years. This can possibly be explained by the fact that a change in the support system is on its way. The fixed remunerations that had been an incremental part of the EEG, are about to run out. As of 2017 wind capacities are called for in tenders that define the compensation. The last project under the fixed remuneration can be finalized in 2018 (BMWi 2018). The effect of this system change cannot be seen in the market development yet but it can be assumed that market players were speeding up their projects to be able to realize them under the old regime (for a similar effect in the PV sector see Klein and Deissenroth 2017).

The development of the number of companies active on the German market also shows the path described by Klepper (1997) (see Fig. 8). Regarding the current status it seems like Germany has been in the phase of market maturity for quite some time now. The majority of wind turbine manufacturers active on the German market have their roots in Germany. The Danish companies that established production locations in Germany did so in the early 1990s. Even though Germany never had any local content requirements, the access to the financing of demonstration projects may have influenced those strategic decisions.

The regression analysis of the development of number of companies with the national development was conducted for two phases (see Annex). The formation phase of the German wind industry could only be analyzed between 1990 and 2000. The early years of the exploratory phase could not be considered as the data on installed capacities for Germany was not available. The results show an adjusted $\mathrm{R}^{2}$ of 0.95 for the industry development with a logarithmic representation of the national wind market. This explanatory value could be slightly improved to 0.97 by adding the rest of the global market development. Just like in the US-American example, this shows the stabilizing role of the global market for individual years of market stagnation or decline. The analysis of the companies that were producing in Germany amounted to an adjusted $\mathrm{R}^{2}$ of 0.94 and 0.98 respectively.

The phase of consolidation that occurred between 2001 and 2016 cannot be statistically explained by the market development. This result is in line with the ILC theory where the shake-out phase does not show an interrelation with the market development. 
The early and relatively stable development of the German market has most likely been one of the reasons for the success of German wind turbine manufacturers. Three of the top 10 global wind turbine manufacturers are located in Germany (see Table 1).

Enercon was founded in 1984 as a spin-off of the University of Braunschweig that had developed a gearless wind turbine under the research program of the federal ministry of research (see also Hoppe-Killper 2003; Maegaard et al. 2013). It is the company with the highest market shares on the German market. Since 1993 the average share has been at $40 \%$ accoding to DEWI (2017). Due to a patent issue, Enercon is the only large European wind turbine manufacturer that is not active on the US market. Enercon has production facilities in 6 countries on the European continent and a subsidiary in Brazil (Wobben Windpower) (Enercon 2018).

Senvion also known under the former name RePower was founded in 2001 in the context of a merger of four German turbine manufacturers. In 2007 it was taken over by Suzlon (IN) as a subsidiary and sold to the US-investment firm Centerbridge in 2015. It is the second largest player on the German market with an average market share of $10 \%$ since 2001 (DEWI 2017).

Nordex SE was founded in 1985 in Denmark. In 1992 it started its production in Germany; in 2001 it became an incorporated company listed on the German stock exchange. In 2003 it closed down its production in Denmark. In 2016 it merged with Acciona Wind Power a renowned turbine manufacturer in Spain (Nordex 2018). Nordex is the third largest company on the German wind market with an average market share of $7 \%$ since 1993 (DEWI 2017).

\subsubsection{India}

India had an installed onshore wind capacity of $29 \mathrm{GW}$ in 2016 with a share of $3.1 \%$ of wind power in the total electricity output (see Table 1). With a wind onshore generation potential of about 1.4 PWh it could theoretically provide its current electricity output. The market conditions in India were relatively stable after the early development phase with a mix of support schemes.

India is the first laggard country that was successful in introducing its own wind manufacturing industry. In 1982 the Indian government started its first research program followed by a demonstration program in 1985. Several investment incentives were set up in 1989 that led to the start of the Indian wind market (Mizuno 2007; Lewis 2011). The introduction of the Electricity Act of 2003 provided the first national legal framework for the promotion of renewable energies in India. It included the request for the introduction of fixed quotas to procure power by the State Electricity Regulatory Commissions. In 2009 a national feed-in tariff system was put in place (IRENA 2012). Just as in Germany, India has currently shifted this system from state-established remunerations to tenders. The market development that can be seen in Fig. 9 shows two cycles of development; a very short one at the beginning of wind utilization in India in the 90s and a relatively stable one since 1998.

The development of companies active on the Indian wind market does not reflect the two cycles of the market development as the data does not cover the first cycle (see Fig. 9). However, the initial market growth of the first development cycle resulted from a strong engagement of foreign companies on the Indian market with its large market potential. During the first cycle almost solely foreign companies were active on the 

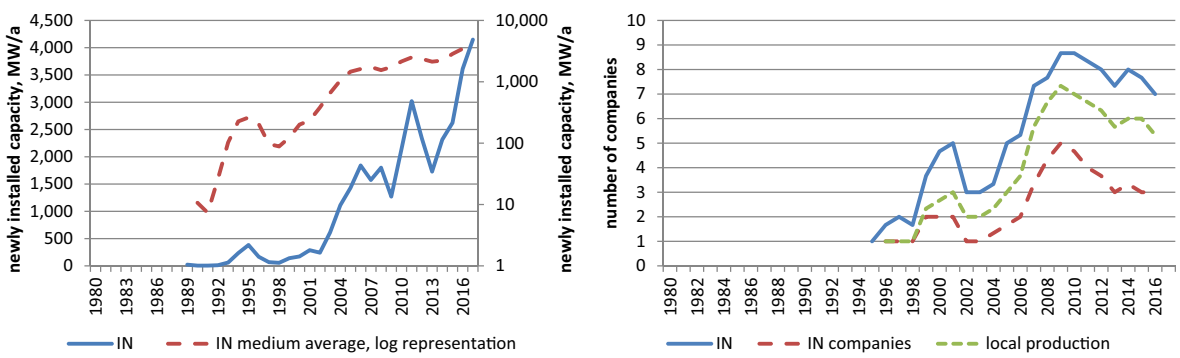

Fig. 9 left: Development of newly installed wind onshore capacity in IN (own representation based on GWEC 2018, BP 2018, Mizuno 2007), right: Development of number of companies in the Indian wind onshore market; IN refers to all companies active in the Indian market, IN companies refers to companies that are based in India, local production refers to companies with a production site in India (own representation based on The Wind Power 2018).

Indian market mostly via subsidiaries that were created as joint ventures. The decline of the market could not harm these global players as dramatically as in the case of new national players in other wind markets as they had the possibility to sell their production in other markets that they were already active in. The development of the national players was initiated during the first cycle but had its real start at the beginning of the second cycle. Just like the US market, the potential offered by the Indian wind energy market brought a number of international companies that built production facilities in India.

The statistical analysis of the period from 1995 to 2016 did not provide a particularly good explanatory value for the industrial development in India. In the growth phase between 1995 and 2009 an adjusted $\mathrm{R}^{2}$ of 0.46 was reached for the number of domestic companies and 0.64 for those with a production in India (see Annex). Those values were significantly higher with the rest of the global market development taken into account as another independent variable. They amounted to 0.89 and 0.92 respectively. Again the consolidation phase did not show any good coefficients of determination. The findings indicate that the global market development played a larger role in the industry development in India than in the other countries that were analyzed so far.

India has also succeeded in establishing one of the top 10 global companies. Suzlon was founded in 1995 and acquiring its technology by way of a technical collaboration with Südwind (DE). Gradually it expanded its production to all components via joint ventures with renowned companies from the US and Europe and took over Germanys RePower (later known as Senvion) in 2007 (Lewis 2011). In 2015 Suzlon sold Senvion keeping an R\&D base in Germany. The company plays a dominant role in the Indian market with an average market share of about $40 \%$ according to the data of the windfarm database. Currently it has production facilities in India and China.

\subsubsection{Spain}

Spain had an onshore wind capacity of $23 \mathrm{GW}$ in 2016 and a share of almost $18 \%$ of wind energy in total electricity output (see Table 1). Its wind onshore generation potential lies just above $3 \mathrm{PWh}$ with a yearly electricity output of around $300 \mathrm{TWh}$. Due to the loss of political support, the Spanish wind energy market has collapsed in the last few years, turning it into one of the unstable markets. 
Political support in Spain started with the first Renewable Energy Plan in 1986. This plan and its successor introduced targets for renewable energy production and investment that focused largely on demonstration projects. The first feed-in tariff system was introduced in 1994. However, the design of this first tariff system did not have the desired effect on the renewable energy market. As a result the Electric Power Act of 1997 introduced a number of significant changes that resulted in a relatively long phase of stable market development (IRENA 2012). This phase ended when the system was adjusted in 2010 and then ceased in 2014 after Spain was severely affected by the global financial crisis in 2009 (IEA/IRENA 2018).

Unfortunately, data for the Spanish market could not be found for the time prior to 1998. From 1998 to 2017 the Spanish market has gone through one cycle with the market falling from almost $2.5 \mathrm{GW}$ in 2009 to zero in 2015. In the last couple of years the demand has picked up very slowly again indicating the beginning of a new period of potential growth (see Fig. 10).

During the market development, four Spanish wind turbine manufacturers entered the market successfully. One reason for this development of national manufacturers can be attributed to local content requirements at that time that were introduced by some Spanish regions in connection with concession tenders (OECD 2015). Those requirements in combination with the strong market development also led to the establishment of two production locations of international wind turbine manufacturers in Spain in 2005. In 2007, at the height of the Spanish market development, Alstom (FR) bought Ecotecnia. The production as well as the headquarters remained in Spain. The crash of the Spanish market in combination with the global financial crisis inevitably had an influence on most of the other Spanish companies. Acciona Windpower was sold to Nordex in 2016, while Gamesa merged with Siemens in 2017.

A statistical analysis of the formative phase of the Spanish wind industry cannot be conducted as numbers on the market development were not available before 1998. By that time Spanish companies were already established. However, the shake-out phase between 2009 and 2016 was statistically analyzed (see Annex). The regression finds an adjusted $\mathrm{R}^{2}$ of 0.54 for the Spanish market development with a positive interrelation between the two decreasing indicators. The additional consideration of the rest of the global market increases the explanatory value to 0.84 . However, the interrelation of the global market development outside of Spain with the Spanish wind industry is
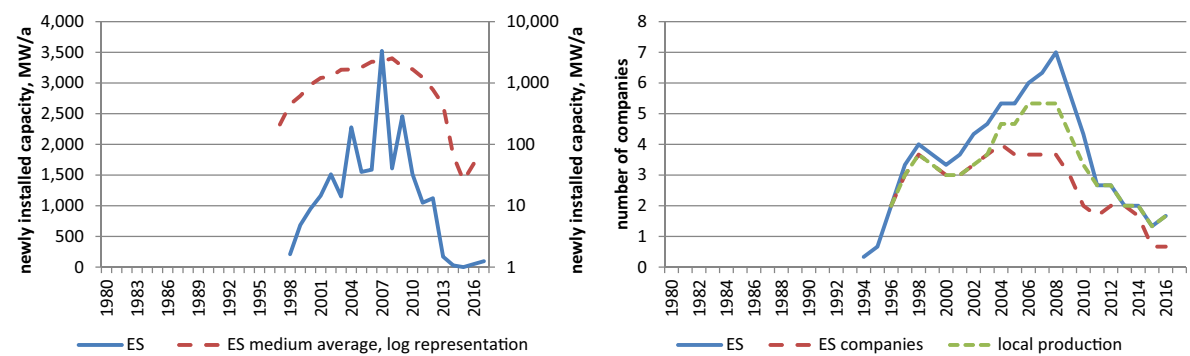

Fig. 10 left: Development of newly installed wind onshore capacity in ES (own representation based on GWEC 2018, BP 2018), right: Development of number of companies in the Spanish wind onshore market; ES refers to all companies active in the Spanish market, ES companies refers to companies that are based in Spain, local production refers to companies with a production site in Spain (own representation based on The Wind Power 2018) (Data on the market development prior to 1998 could not be determined). 
negative. The values for the number of companies with local production are at 0.88 and 0.87 respectively. Overall, this analysis shows a considerable influence of the national market development on the consolidation of the Spanish wind industry.

The one Spanish turbine manufacturers that shows up in the top 10 of global companies is Gamesa. It was founded in 1994 at the beginning of wind utilization in Spain with Vestas being involved as technical partner holding a share of $40 \%$ of the company. This joint venture can be attributed to the local content requirements of Spanish regional energy policies at that time. It enabled Vestas to get access to the Spanish market as a whole (IRENA 2012). In 2017 Gamesa was merged with Siemens to form Siemens-Gamesa.

\subsubsection{China}

The Chinese wind energy market is currently by far the largest in the world. About 147 GW were installed until 2016, about one third of the global capacity. Chinas overall electricity output is also the largest in the world with about 6 PWh per year of which about $3.2 \%$ are provided by wind energy. The yearly wind onshore generation potential is estimated to be around $34 \mathrm{PWh}$ (see Table 1 and Table 2). Up to this point, wind market conditions in China can be regarded as relatively stable.

China is often considered to be the country that successfully managed to catch-up in many technologies. This also applies for wind energy. In China the five year plans of the government are the foundation of political support. In the Ninth five year plan a first basis was set to develop a national wind energy industry by introducing an R\&D program in 1996. The first market pull was initialized by the "Renewable Energy Law of the People's Republic of China" in 2005 which led to the introduction of feed-in tariffs in 2009 (Wang et al. 2012, Klagge et al. 2012).

Due to this support system the Chinese market has seen an exponential growth for a good few years with levels between $12 \mathrm{GW}$ and $31 \mathrm{GW}$ per year since 2009, in which the Chinese market covered more than one third of the yearly global market. The decline in installations in 2012 that can be seen in Fig. 11 can be explained by the change in approval procedures which were introduced due to grid congestions.

The number of companies active on the Chinese market has steadily risen along with the market development. The statistical analysis of the period between 1999 and 2012 provides an adjusted $\mathrm{R}^{2}$ of 0.91 for the development of national based companies that is
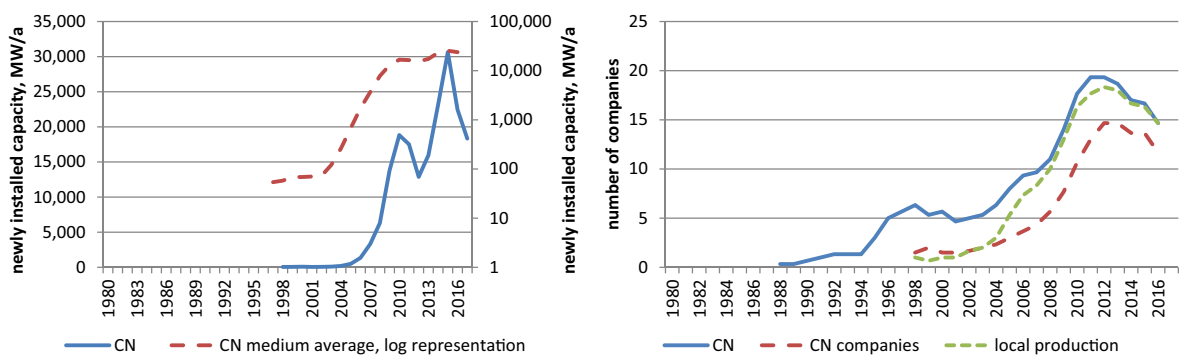

Fig. 11 left: Development of newly installed wind onshore capacity in $\mathrm{CN}$ (own representation based on GWEC 2018, BP 2018), right: Development of number of companies in the Chinese wind onshore market; $\mathrm{CN}$ refers to all companies active in the Chinese market, $\mathrm{CN}$ companies refers to companies that are based in China, local production refers to companies with a production site in China (own representation based on The Wind Power 2018)(Data on the market development prior to 1998 could not be determined). 
not improved by the integration of the rest of the world (see Annex). The development of companies with local production in China amounts to an adjusted $\mathrm{R}^{2}$ of 0.92 which is increased to 0.97 including the rest of the world.

The development of the number of companies indicates that the Chinese market has possibly entered a phase of maturation. A consolidation of manufacturers has started that will presumably continue in the coming years (see Fig. 11). The statistical analysis of these last four years has to be treated with caution due to the low number of observations. It shows no significance or relevant coefficient of determination for the national companies or companies with local production in China.

The development of the wind industry in China follows the same pattern as in India. The beginning of market development was strongly influenced by global wind industry players followed by the rise of national companies that acquired their technologies through licenses and joint ventures (Lewis and Wiser 2007; Lewis 2011; Wang et al. 2012). Local content requirements were introduced in 2003 that led to the development of manufacturing locations of international companies in China (OECD 2015).

Regarding the development of a national industry, China has succeeded in establishing three of the top 10 global wind turbine manufacturers. The largest player on the Chinese market with an average market share of $23 \%$ since 2002 is Goldwind. It was founded in 1998 with a production agreement of a $600 \mathrm{~kW}$ turbine from Jacobs (DE) followed by a license to produce a $750 \mathrm{~kW}$ turbine of RePower. In 2003 Goldwind signed a cooperation agreement with Vensys, a wind technology developer in Germany, of which it acquired the majority in 2008 (Maegaard et al. 2013).

Next to Goldwind there are a number of Chinese wind turbine manufacturers, of which most started their business between 2006 and 2009. Many of these companies started of using technology from second or third tier wind companies from more advanced wind energy markets, often using one form or another of technology transfer mechanism. However, most of them have moved on and are developing their own technology by now even though there might be doubt that the degree of innovation is as high as it might be expected (Lewis and Wiser 2007; Lewis 2011; Wang et al. 2012; Maegaard et al. 2013; Lam et al. 2017; Quitzow et al. 2017; Sahu 2018). The two currently showing up in the top 10 are Guodian United Power which was founded in 2009 as a subsidiary of one of the largest Chinese power suppliers and Envision which started its business in 2008 .

\subsubsection{Comparison of national developments}

The comparison of the six countries analyzed so far shows that industry life cycles can be identified on a national level. Even though all of them seem to have entered a phase of maturation they differ in the point in time when the development has started and when the third phase of maturity was reached. Also it became evident that a interdependency exists between the development of the market and its respective players. The formation phase of the national wind industries shows a particularly strong coefficient of determination with the market development for most of the analyzed countries. However, no uniform statements can be made with regard to the shake-out phase. A relevant interrelation between market development and industrial development could only be 


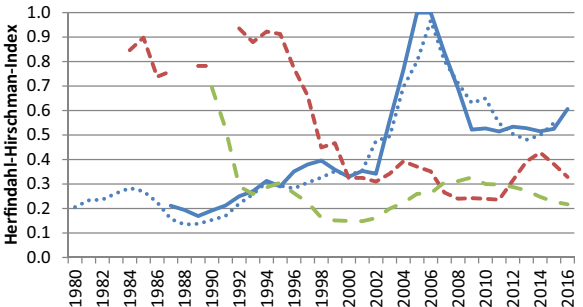

DK …. DK DEA $=--$ US - - DE

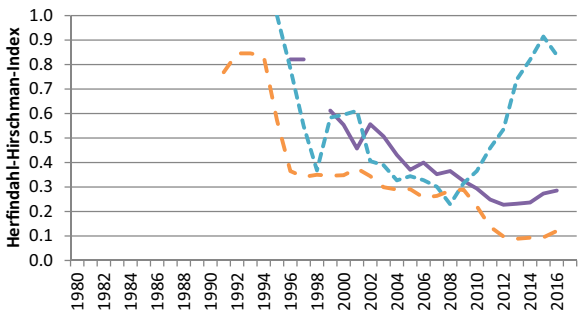

$\longrightarrow \mathrm{IN}=-\mathrm{ES}-\mathrm{CN}$

Fig. 12 Market concentration in selected wind onshore markets (own representation based on The Wind Power 2018, Danish Energy Agency 2017)

shown in those cases in which a strong market decline was observed. This leads to the conclusion that a decline of national markets reduces national players earlier and maybe even further than under stable market conditions. The early shake out of companies also seems to have a lasting effect as a renewed upturn in the market in Denmark or the US did not seem to increase the number of local companies significantly.

Looking at the development of market concentration on these national markets (see Fig. 12) in comparison to the market concentration on the global onshore wind market (see Fig. 4 d) it can be seen that they do not have the same level of competitiveness as the global market. Those markets with instable market developments also show higher levels of market concentration. At the same time a relatively high market concentration could be determined even in the markets with stable market development. Each one of those markets has one to two relevant national players that dominate the market they are based in. This indicates that national players have a better market position in their home market than their international competitors. This aspect will be further analyzed by looking into the other six national markets that were selected in Table 1 that are not home to one of the global top 10 companies.

Figure 13 displays the same indicators as Fig. 4. Three countries are presented together in one graph. On the left hand side the developments of the UK (GB), Canada (CA) and France (FR) are shown. Brazil (BR), Ireland (IE) and Portugal (PT) are displayed on the right hand side. The development of each of these countries is shown as of 1998 as no earlier data was available.

On the left hand side, the UK, ${ }^{4}$ Canada $^{5}$ and France have all had a relatively stable market development and seem to have reached the phase of maturation (see Fig. 13 a) and b)). The development of the companies' active in each one of those markets also supports the observation that these countries have reached a phase of maturation (see Fig. 13 c)). Of the three countries only France has seen a small development of national wind turbine manufacturers. While Canada has tried to establish local production of

\footnotetext{
${ }^{4}$ The strong increase of installations in the UK in 2017 can be traced back to the change in the political support system. Developers seem to have tried to meet the deadline so that their projects still have access to the old support regime. A similar effect was seen in Germany and India, as indicated above.

${ }^{5}$ The strong decrease in installations in Canada in 2017 cannot be explained. There is no indication that the Canadian wind market is not supported by the political regime. Therefore installations in 2018 should pick up again.
} 

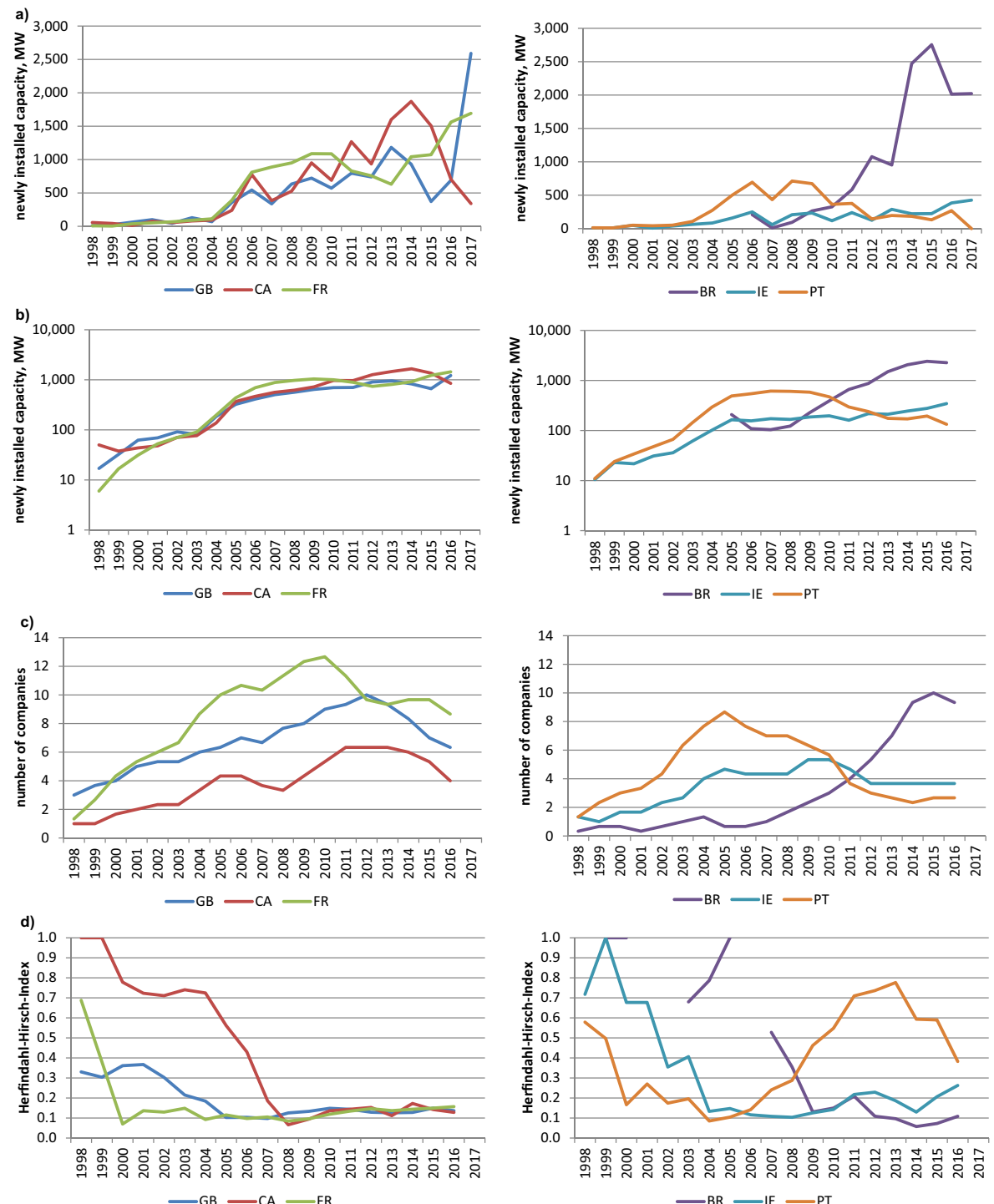

Fig. 13 a Development of newly installed wind onshore capacity in selected markets (own representation based on GWEC 2018, BP 2018), b Logarithmic representation of the development of newly installed capacity, moving average (see Fig. 6 a) c Development of number of companies in selected wind onshore markets (own representation based on The Wind Power 2018), d Market concentration in selected wind onshore markets (own representation based on The Wind Power 2018)

onshore wind turbine manufacturers by implementing local content requirements in its political support systems, the UK and France have put their focus on the establishment of an offshore wind industry and did not introduce local content requirements for the onshore market. The results are not that different; two international wind turbine manufacturers opened manufacturing locations in Canada whereas one each established a production site in the UK and France. 
On the right hand side of Fig. 13 two different types of markets are displayed. The Brazilian market has a large potential for the utilization of wind power whereas Ireland and Portugal have good wind resources but electricity demand is low. Ireland's electricity demand in 2015 was 5\% that of the Brazilian market and Portugal's 9\% (see Table 2).

Looking at the development of the Brazilian ILC it is not clear if Brazil is currently still in its growth phase as it shows some signs of maturation. ${ }^{6}$ So far, all political support schemes for wind energy introduced in Brazil had very high local content requirements (IRENA 2012). Several companies have set up production facilities in Brazil and two Brazilian wind turbine manufacturers emerged, one being a subsidiary of Enercon (DE).

The markets in Ireland ${ }^{7}$ and Portugal $^{8}$ on the other hand already entered the maturation phase in the mid-2000s. The Irish wind market is exclusively served by imported wind turbines whereas two international wind manufacturers opened production facilities in Portugal which might be attributed to local content requirements introduced in 2005.

Looking at the market concentration of the six markets displayed in Fig. 13, it can be seen that a much higher level of competition is reached in each one of those markets than in the ones displayed in Fig. 12 (see Fig. 13 d)). The market concentration in the Brazilian market has reached a similar low level as in the other three examples on the left hand side of the figure. The market concentration in Ireland and Portugal, however, seems not to be as low and stable. Looking into the data more closely it can be observed that these two markets are on a level of market size at which individual wind farms have a large influence on the overall numbers.

In order to find an explanation as of why the countries without one of the top 10 global wind turbine manufacturers seem to have a more competitive market situation than the ones with a successful global player, an analysis of the market shares of companies in each respective market was conducted.

Figure 14 shows the cumulative market shares of companies from different countries over time in different markets. The companies that are based in the country under examination are referred to as local companies and are displayed first. The countries with one of the top 10 wind turbine manufacturers are displayed in the graph on the left hand side, the ones without on the right.

What can be observed immediately is that the capacities for the markets in the left graph are largely provided by local companies. The countries in the right graph have hardly any to none local companies that supplied the markets with wind turbines. Again it needs to be stressed that this does not mean that no production sites can be found in those countries. The difference is that these production sites are run by companies based in other countries. These results therefore show that a stronger market

\footnotetext{
${ }^{6}$ The Brazilian wind market development is not fully represented in the graph. It started in 2002 with the introduction of a feed in tariff system that was replaced by a series of tenders in 2009.

${ }^{7}$ The Irish development started in 1993 with tenders that were replaced by a feed-in tariff system in 2006. Just like in Germany and India the feed-in tariff system is to be replaced by tenders, which explains the relatively strong expansion in the last two years.

${ }^{8}$ It cannot be explained why no onshore installations were seen in Portugal in 2017. However, Portugal has already exceeded its wind energy goals for 2020 .
} 

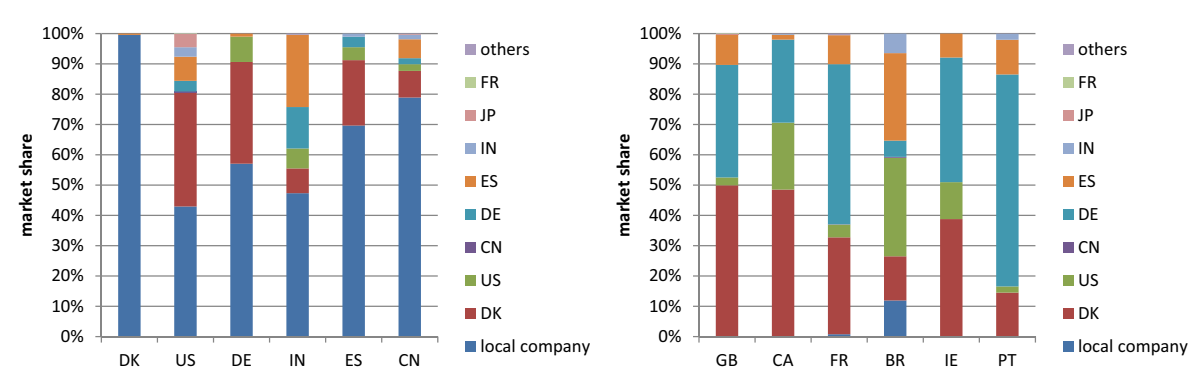

Fig. 14 Market share of companies based in different countries on selected markets (own representation based on The Wind Power 2018)

concentration can be expected in markets that have succeeded to establish their own companies.

Another aspect which can be seen in Fig. 8 is the role of the size of a market in the global company rankings. Chinese companies for example of which three are in the top 10 global wind turbine manufacturers are mainly active in their home market. As the Chinese wind turbine market has had extraordinary growth in the last few years, it is not surprising that the engagement of Chinese companies was limited in other national markets. However, it shows that the entrance of a large market like the Chinese, that is by far the largest in the world, can be sufficient to change the ranking of global players without the other companies losing their relevance in other national developments.

\section{Conclusions}

The analysis of the industry life cycle of the wind energy sector has shown that the global development of wind energy markets as well as market participants derives from the sum of individual national developments. Each national market has an influence on the development of the global market. How strong this influence is depends on the size of the national market in comparison to the global market in each year. However, the relevance of the national perspective regarding the industrial development cannot be seen in the research that focuses on the creation of innovation. The results of this research indicate that the creation of innovation is subject to a global knowledge base (Huenteler et al. 2016). Therefore, the question as to which geographical boundaries are important for the ILC in a globalized world cannot be answered unequivocally. Knowledge and the creation of innovation generally seem to be distributed globally whereas market creation and industrial development are strongly influenced by national developments.

Looking at the national level a few different findings should be pointed out. Regarding the development phases of the wind industry life cycle, it could be observed that all the countries analyzed in this paper have reached the various stages at different points in time. Regarding the development paths various insights can be gained. First of all there were national wind markets with relatively stable market conditions. The development of these markets as well as the development of the number of companies active on these markets did follow the path described by Klepper's (1997) ILC theory. Other national markets did not have the same stability in political support which 
resulted in an unstable demand for wind turbines. Especially changes in effective support systems created an escalating demand followed by a strong reduction in the market. The development of those markets followed a number of cycles that included all four phases described by the PLC theory (see Levitt 1965). What is particularly noteworthy is the relevance of the forth development phase in this context. Usually it is only relevant for industries and their technologies that disappear from a market. In the case of the wind industry the relevance of the technology for the energy market remains high. However, the consequences of market decline for the industry providing the technology were extensive. Those countries that had been able to establish their own wind turbine manufacturers saw an early consolidation of their firms that reduced national players dramatically. This led to a higher concentration on the respective markets. Even though the market concentration was reduced in later phases of market expansion once again, the dominating role of the few companies that remained after the initial shakeout phase persisted. Also, once a national market had seen a severe consolidation of its local market players, new company formations in later cycles never even closely reached the level of the first cycle again. Another interesting aspect is the dominance of home based companies. Those countries that succeed in establishing domestic wind turbine manufacturers did see a higher market concentration than those without. This is the case for all countries, regardless of the stability of their respective market development.

Looking at the establishment of companies quite a few different insights could be gained. After the initial introduction of wind energy technology in the lead market Denmark around 1980, the potential of each respective market and its stable development seem to have been a very important factor in the success to establish national based companies. The importance of this factor appears to be growing as companies from other countries get established on the global market. The Spanish market for example was able to provide enough potential for its own industry to develop in the mid-90s whereas ten years later similar market developments in countries like Italy, France, UK, South Africa, Chile or Mexico did not initiate the same dynamic. The Chinese market on the other hand was able to create its own industry around that time. The sheer size of the Chinese market even made it possible that companies that are basically only active in their home market show up in the top ranking of global players. The aspect of national market size therefore seems to be an issue that needs to be addressed in further research regarding catch-up cycles in industrial leadership.

Another factor that seems to influence the ability to establish a local value chain is the proximity to countries that already have succeeded in their efforts. As the number of countries active in a technology is growing this factor gains importance. After the successful establishment of Danish, German and Spanish companies no other European country has succeeded in establishing its own wind companies. The same goes for Canada which does have a relatively large market potential but is located in close vicinity to the already established US wind market. Another example is South Korea. Five large international Korean based technology companies tried to enter the wind turbine market around 2010, so far none of them succeeded as the Chinese market and its established value chain dominates the industrial development in this region.

Policy approaches to establish a home based wind turbine industry are essentially based on the creation of a national market with the help of different support mechanisms often combined with direct or indirect local content requirements. Most of these approaches are focused on the onshore wind market but some countries have started to 
focus on the establishment of companies and value chains in the new offshore wind trajectory. This can especially be seen in Europe where the onshore wind value chain is already established and market dynamics do not seem to leave much room for further expansion. The question of the effects of local content requirements on the industrial development is too large to be answered in this paper. However, the findings do indicate that local content requirements only had a secondary effect on the establishment of wind turbine manufacturers. The two aspects of market potential and the proximity to markets with established value chains do seem to have a larger influence on the strategic location decisions of companies.

Another aspect that can be added to the findings are the approaches of companies to either gain access to the wind energy technology in the catch-up process or on the flipside the approaches of companies to gain excess to new markets. The historic development of various companies described in this paper shows that technological knowledge was widely acquired from the knowledge base of already existent markets due to collaborations, licensing production or company acquisition. The acquisition of already established companies was especially chosen by large technology groups. As wind energy was introduced by a bottom up approach large technology groups entered the market at a later point in time, mostly when their home markets showed a relatively reliable market development. The role of the technology introduced by Vestas in the creation of many companies stands out especially. The very open approach to share the knowledge regarding their technology derives from the background this company originated in. It could be argued that this open approach contributed to the successful introduction of wind energy technology on a global level by helping to avoid potential obstacles that might have had a negative effect on the acceptance and therefore would have slowed down the diffusion. The reasons for companies to cooperate or hand out licenses for the production of their technologies can be explained by strategic considerations. The wind turbine industry in its beginning consisted of small to medium enterprises that tried to enter new arising markets and at the same time limit the risks that come with those expansions. Collaborations were the initial approach to enter new markets beyond exports, often initiated by local content requirements. As successful turbine manufacturers started to set up their own production facilities in other countries their need for collaborations was reduced. However, second or third tier wind companies from more advanced wind energy markets continued to provide technological collaborations for companies in other countries that were interested in investing in wind energy technology. Another strand of companies that evolved in the aftermath of the initial establishment of wind energy production in some established countries were engineering companies that often had strong links to research institutions. These companies develop and design wind turbines to sell licenses for production. For the most part these licenses were not bought by national wind turbine manufacturers as they already had their own technology at hand. Also, no new wind turbine manufacturers tried to enter those markets as laggards had difficulties to establish in their home markets that were dominated by already established national companies. Therefore, the licenses were mainly sold to companies in emerging markets.

Regarding the relocation of production to countries with cost advantages in later stages of ILCs as mentioned in literature (Vernon 1966, 1979), no such development could be observed in wind energy so far. The proximity to the respective national markets that set of an industry development does seem to remain important even in the 
maturity phase of the ILC. One reason might be the market position local companies have in their home countries; another might be the innovation base of those countries. One circumstance that supports this thesis is that Suzlon maintained an R\&D location in Germany even after leaving the German market by selling Senvion.

It cannot be answered so far if the findings in this paper hold true for other technologies and their industries with changing political support that results in unstable market conditions. This question will have to be subject to further research.

Also, it should be stressed that this paper does not try to argue that industrial development solely depends on market development. As Porter (1990) has shown in his diamond model there are many more factors that influence the success of a nations industry.

However, the paper shows that fundamental changes in political support for wind energy not only had an effect on the market development, as discussed in literature, but also on the national based industry that provides the technology. This aspect should be taken into consideration in the further development of policy frameworks for wind energy.

Funding information Open Access funding provided by Projekt DEAL.

\section{Compliance with ethical standards}

The work was carried out within the framework of two research projects: a) "Network analysis and simulation of innovation dynamics of new key technologies in the energy sector" (03ET4032B) funded by the German Federal Ministry of Economic Affairs and Energy within the scope of the 6th Energy Research Programme of the Federal Government; b) "The 'System integration' Kopernikus project: Energiewende navigation system" (03ET4032B) funded by the German Federal Ministry of Education and Research.

\section{Annex}

\section{Regression Statistics}

\section{Global}

\begin{tabular}{lllllll}
\hline & $1978-1985^{+}$ & $1986-1993$ & $1994-2000^{+}$ & $2001-2003$ & $2004-2011$ & $2012-2016$ \\
\hline$I$ & $I I$ & $I I I$ & $I V$ & $V$ & $V I$ & \\
$\mathrm{R}^{2}$ & 0.98 & 0.56 & 0.97 & 0.15 & 0.99 & 0.93 \\
Adjusted R & 0.97 & 0.49 & 0.96 & -0.70 & 0.98 & 0.90 \\
Standard Error & 1.63 & 4.32 & 0.82 & 1.09 & 1.45 & 2.51 \\
Observations (n) & 8 & 8 & 7 & 3 & 8 & 5 \\
Coefficients & & & & & & \\
Intercept & 7.1501446 & 32.4083155 & -29.4901785 & 27.4819094 & 14.4185171 & 97.1406868 \\
global MW/a & $3.65433 * * *$ & $-0.04468 *$ & $6.63432 * * *$ & -0.00033 & $0.00096 * *$ & $-0.00117 * *$ \\
\hline
\end{tabular}

$+\ln (\mathrm{MW} / \mathrm{a})$

$* * * p<0.001 * * p<0.01 * p<0.05 . p<0.1$ 


\section{Denmark}

Domestic companies.

\begin{tabular}{|c|c|c|c|c|c|}
\hline & $1978-1989^{+}$ & $1990-1993$ & 1994-1997 & $1998-2006$ & $2007-2016$ \\
\hline$I$ & II & III & $I V$ & $V$ & \\
\hline $\mathrm{R}^{2}$ & 0.95 & 0.87 & 0.78 & 0.78 & 0.83 \\
\hline Adjusted $\mathrm{R}^{2}$ & 0.94 & 0.81 & 0.67 & 0.75 & 0.81 \\
\hline Standard Error & 1.11 & 1.59 & 0.60 & 1.72 & 0.20 \\
\hline Observations (n) & 12 & 4 & 4 & 9 & 10 \\
\hline \multicolumn{6}{|l|}{ Coefficients } \\
\hline Intercept & 7.7706191 & -3.2016369 & 9.8155185 & 1.0315811 & 1.2720830 \\
\hline $\mathrm{DK} \mathrm{MW} / \mathrm{a}$ & $2.65148 * * *$ & 0.29747 & 0.00940 & $0.01862 * *$ & $0.00526 * *$ \\
\hline \multicolumn{6}{|l|}{$+\ln (\mathrm{MW} / \mathrm{a})$} \\
\hline \multicolumn{6}{|c|}{$* * * \mathrm{p}<0.001 * * \mathrm{p}<0.01 * \mathrm{p}<0.05 . \mathrm{p}<0.1$} \\
\hline & $1978-1989^{+}$ & 1990-1993 & 1994-1997 & 1998-2006 & 2007-2016 \\
\hline$I$ & II & III & $I V$ & $V$ & \\
\hline $\mathrm{R}^{2}$ & 0.97 & 0.92 & 0.99 & 0.85 & 0.95 \\
\hline Adjusted $\mathrm{R}^{2}$ & 0.96 & 0.75 & 0.97 & 0.80 & 0.94 \\
\hline Standard Error & 0.92 & 1.81 & 0.17 & 1.51 & 0.11 \\
\hline Observations (n) & 12 & 4 & 4 & 9 & 10 \\
\hline \multicolumn{6}{|l|}{ Coefficients } \\
\hline Intercept & 8.1987535 & 19.6636503 & 20.3982751 & 6.6702630 & 0.6923504 \\
\hline DK MW/a & $3.13822 * * *$ & 0.00913 & 0.08060 & 0.00750 & 0.00181 \\
\hline global w/o DK MW/a & $-0.42306^{*}$ & -0.02847 & -0.02077 & -0.00048 & $0.00003 * *$ \\
\hline
\end{tabular}

\footnotetext{
$+\ln (\mathrm{MW} / \mathrm{a})$

$* * * \mathrm{p}<0.001 * * \mathrm{p}<0.01 * \mathrm{p}<0.05 . \mathrm{p}<0.1$
} 


\section{United States of America}

Domestic companies.

\begin{tabular}{|c|c|c|c|c|}
\hline & $1982-1984^{+}$ & 1985-1994 & $1995-2011$ & 2012-2016 \\
\hline$I$ & II & III & $I V$ & \\
\hline $\mathrm{R}^{2}$ & 0.95 & 0.96 & 0.89 & 0.02 \\
\hline Adjusted $\mathrm{R}^{2}$ & 0.90 & 0.95 & 0.88 & -0.31 \\
\hline Standard Error & 0.41 & 0.42 & 0.44 & 1.52 \\
\hline Observations (n) & 3 & 10 & 17 & 5 \\
\hline \multicolumn{5}{|l|}{ Coefficients } \\
\hline Intercept & -1.4984664 & -0.5957625 & 0.6492829 & 3.4918708 \\
\hline US MW/a & 1.73805 & $0.02048 * * *$ & $0.00038 * * *$ & -0.00015 \\
\hline \multicolumn{5}{|l|}{$+\ln (\mathrm{MW} / \mathrm{a})$} \\
\hline \multicolumn{5}{|c|}{$* * * \mathrm{p}<0.001 * * \mathrm{p}<0.01 * \mathrm{p}<0.05 . \mathrm{p}<0.1$} \\
\hline & $1982-1984^{+}$ & 1985-1994 & 1995-2011 & $2012-2016$ \\
\hline$I$ & $I I$ & $I I I$ & $I V$ & \\
\hline $\mathrm{R}^{2}$ & 1.00 & 0.96 & 0.98 & 0.99 \\
\hline Adjusted $\mathrm{R}^{2}$ & $65,535.00$ & 0.95 & 0.97 & 0.99 \\
\hline Standard Error & 0.00 & 0.45 & 0.20 & 0.15 \\
\hline Observations (n) & 3 & 10 & 17 & 5 \\
\hline \multicolumn{5}{|l|}{ Coefficients } \\
\hline Intercept & -3.3166250 & -0.6684231 & 0.3794422 & 10.8225960 \\
\hline US MW/a & 2.39867 & $0.02073 * * *$ & -0.00005 & -0.00001 \\
\hline global w/o US MW/a & -0.88424 & 0.00021 & $0.00014 * * *$ & $-0.00020 * *$ \\
\hline
\end{tabular}

\footnotetext{
$+\ln (\mathrm{MW} / \mathrm{a})$
}

$* * * \mathrm{p}<0.001 * * \mathrm{p}<0.01 * \mathrm{p}<0.05 . \mathrm{p}<0.1$ 
Companies with local production.

\begin{tabular}{|c|c|c|c|c|}
\hline & $1982-1984^{+}$ & 1985-1994 & $1995-2011$ & $2012-2016$ \\
\hline$I$ & II & III & IV & \\
\hline $\mathrm{R}^{2}$ & 0.95 & 0.96 & 0.95 & 0.02 \\
\hline Adjusted $\mathrm{R}^{2}$ & 0.90 & 0.95 & 0.94 & -0.31 \\
\hline Standard Error & 0.41 & 0.42 & 0.78 & 2.34 \\
\hline Observations (n) & 3 & 10 & 17 & 5 \\
\hline \multicolumn{5}{|l|}{ Coefficients } \\
\hline Intercept & -1.4984664 & -0.5957625 & 0.2147455 & 8.2019536 \\
\hline US MW/a & 1.73805 & $0.02048 * * *$ & $0.00101 * * *$ & -0.00022 \\
\hline \multicolumn{5}{|l|}{${ }^{+} \ln (\mathrm{MW} / \mathrm{a})$} \\
\hline \multicolumn{5}{|c|}{$* * * \mathrm{p}<0.001 * * \mathrm{p}<0.01 * \mathrm{p}<0.05 . \mathrm{p}<0.1$} \\
\hline & $1982-1984^{+}$ & 1985-1994 & 1995-2011 & 2012-2016 \\
\hline$I$ & II & III & $I V$ & \\
\hline $\mathrm{R}^{2}$ & 1.00 & 0.96 & 0.99 & 0.99 \\
\hline Adjusted $\mathrm{R}^{2}$ & $65,535.00$ & 0.95 & 0.99 & 0.98 \\
\hline Standard Error & 0.00 & 0.45 & 0.40 & 0.27 \\
\hline Observations (n) & 3 & 10 & 17 & 5 \\
\hline \multicolumn{5}{|l|}{ Coefficients } \\
\hline Intercept & -3.3166250 & -0.6684231 & -0.2529145 & 19.5261266 \\
\hline US MW/a & 2.39867 & $0.02073 * * *$ & 0.00025 & 0.000004 \\
\hline global w/o US MW/a & -0.88424 & 0.00021 & $0.00024 * * *$ & $-0.00032 * *$ \\
\hline
\end{tabular}

$+\ln (\mathrm{MW} / \mathrm{a})$

$* * * \mathrm{p}<0.001 * * \mathrm{p}<0.01 * \mathrm{p}<0.05 . \mathrm{p}<0.1$ 


\section{Germany}

Domestic companies.

\begin{tabular}{lcccc}
\hline \multicolumn{4}{c}{$1990-2000^{+}$} & \multicolumn{3}{c}{$2001-2016$} \\
\hline$I$ & $I I$ & $I I I$ & $I V$ & 0.38 \\
$\mathrm{R}^{2}$ & 0.95 & 0.97 & 0.16 & 0.28 \\
Adjusted R & & 0.97 & 0.62 \\
Standard Error & 0.95 & 0.49 & 0.70 & 16 \\
Observations (n) & 0.64 & 11 & 16 & 6.4290006 \\
Coefficients & 11 & & 6.3553076 & -0.00009 \\
Intercept & & -11.8280241 & -0.00030 & $-0.00002 *$ \\
DE MW/a & -7.3283847 & 0.67033 & & \\
global w/o DE MW/a & $2.04183 * * *$ & $1.92694 *$ & & \\
\hline
\end{tabular}

$+\ln (\mathrm{MW} / \mathrm{a})$

$* * * \mathrm{p}<0.001 * * \mathrm{p}<0.01 * \mathrm{p}<0.05 . \mathrm{p}<0.1$

Companies with local production.

\begin{tabular}{lcccl}
\hline & 1990-2000+ & & $2001-2016$ & \\
\hline$I$ & $I I$ & $I I I$ & $I V$ & \\
$\mathrm{R}^{2}$ & 0.95 & 0.98 & 0.12 & 0.35 \\
Adjusted R & 0.94 & 0.98 & 0.06 & 0.25 \\
Standard Error & 0.84 & 0.56 & 0.69 & 0.62 \\
Observations (n) & 11 & 11 & 16 & 16 \\
Coefficients & & & & \\
Intercept & -9.8408745 & -16.5093094 & 8.2586761 & 8.3303722 \\
DE MW/a & $2.65364^{* * *}$ & 0.62109 & -0.00025 & -0.00005 \\
global w/o DE MW/a & & $2.85570^{* *}$ & & -0.00002. \\
\hline
\end{tabular}

$+\ln (\mathrm{MW} / \mathrm{a})$

$* * * p<0.001 * * p<0.01 * p<0.05 . p<0.1$ 


\section{India}

Domestic companies.

\begin{tabular}{lllll}
\hline & $1995-2009$ & & $2010-2016$ & \\
\hline$I$ & $I I$ & $I I I$ & $I V$ & \\
$\mathrm{R}^{2}$ & 0.50 & 0.90 & 0.22 & 0.58 \\
Adjusted R & 0.46 & 0.89 & 0.07 & 0.37 \\
Standard Error & 0.98 & 0.45 & 0.61 & 0.50 \\
Observations (n) & 15 & 15 & 7 & 7 \\
Coefficients & & & & \\
$\quad$ Intercept & 0.8442831 & 0.7871978 & 5.0804225 & 6.6257236 \\
IN MW/a & $0.00140^{* *}$ & -0.00070. & -0.00062 & 0.00019 \\
global w/o IN MW/a & & $0.00018^{* * *}$ & & -0.00008 \\
\hline
\end{tabular}

$* * * p<0.001 * * p<0.01 * p<0.05 . p<0.1$

Companies with local production.

\begin{tabular}{lllll}
\hline & $1995-2009$ & \multicolumn{3}{l}{$2010-2016$} \\
\hline$I$ & $I I$ & $I I I$ & $I V$ & 0.52 \\
$\mathrm{R}^{2}$ & 0.67 & 0.93 & 0.32 & 0.29 \\
Adjusted R $^{2}$ & 0.64 & 0.92 & 0.19 & 0.48 \\
Standard Error & 1.27 & 0.60 & 0.52 & 7 \\
Observations (n) & 15 & 15 & 7 & 8.8880006 \\
Coefficients & & & & -0.00012 \\
Intercept & 0.9633491 & 0.8900610 & 7.8375969 & -0.00006 \\
IN MW/a & $0.00256^{* * *}$ & -0.00014 & -0.00067 & \\
global w/o IN MW/a & & $0.00022^{* * * *}$ & & \\
\hline
\end{tabular}

$* * * \mathrm{p}<0.001 * * \mathrm{p}<0.01 * \mathrm{p}<0.05 . \mathrm{p}<0.1$ 


\section{Spain}

Domestic companies.

\begin{tabular}{lll}
\hline & $2009-2016$ & \\
\hline$I$ & $I I$ & 0.89 \\
$\mathrm{R}^{2}$ & 0.61 & 0.84 \\
Adjusted R & 0.54 & 0.30 \\
Standard Error & 0.52 & 8 \\
Observations (n) & 8 & 7.2266962 \\
Coefficients & & -0.00040 \\
Intercept & 1.0961985 & $-0.00012^{*}$ \\
ES MW/a & $0.00080^{*}$ & \\
global w/o ES MW/a & & \\
\hline
\end{tabular}

$* * * \mathrm{p}<0.001 * * \mathrm{p}<0.01 * \mathrm{p}<0.05 . \mathrm{p}<0.1$

Companies with local production.

\begin{tabular}{lll}
\hline & $2009-2016$ & \\
\hline$I$ & $I I$ & \\
$\mathrm{R}^{2}$ & 0.89 & 0.91 \\
Adjusted R & 0.88 & 0.87 \\
Standard Error & 0.34 & 0.35 \\
Observations (n) & 8 & 8 \\
Coefficients & & \\
Intercept & 1.553632 & 3.369052 \\
ES MW/a & $0.00124^{* * * *}$ & 0.00088. \\
global w/o ES MW/a & & -0.00004 \\
\hline
\end{tabular}

$* * * \mathrm{p}<0.001 * * \mathrm{p}<0.01 * \mathrm{p}<0.05 . \mathrm{p}<0.1$ 


\section{China}

Domestic companies.

\begin{tabular}{lllll}
\hline & $1999-2012$ & & $2013-2016$ & \\
\hline$I$ & $I I$ & $I I I$ & $I V$ & \\
$\mathrm{R}^{2}$ & 0.92 & 0.92 & 0.34 & 0.61 \\
Adjusted R & 0.91 & 0.91 & 0.02 & -0.17 \\
Standard Error & 1.40 & 1.39 & 1.25 & 1.36 \\
Observations (n) & 14 & 14 & 4 & 4 \\
Coefficients & & & & \\
Intercept & 1.594155 & 0.439332 & 18.107248 & 23.467314 \\
CN MW/a & $0.00064 * * *$ & $0.00050^{* *}$ & -0.00021 & -0.00007 \\
global w/o CN MW/a & & 0.00014 & & -0.00032 \\
\hline
\end{tabular}

$* * * \mathrm{p}<0.001 * * \mathrm{p}<0.01 * \mathrm{p}<0.05 . \mathrm{p}<0.1$

Companies with local production.

\begin{tabular}{lllll}
\hline & $1999-2012$ & & $2013-2016$ & \\
\hline$I$ & $I I$ & $I I I$ & $I V$ & \\
$\mathrm{R}^{2}$ & 0.93 & 0.97 & 0.59 & 0.77 \\
Adjusted R & 0.92 & 0.97 & 0.38 & 0.30 \\
Standard Error & 1.86 & 1.18 & 1.18 & 1.26 \\
Observations (n) & 14 & 14 & 4 & 4 \\
Coefficients & & & & \\
Intercept & 2.662406 & -1.056491 & 23.829339 & 29.048575 \\
CN MW/a & $0.00093^{* * *}$ & $0.00048^{* *}$ & -0.00033 & -0.00019 \\
global w/o CN MW/a & & $0.00046^{* *}$ & & -0.00031 \\
\hline
\end{tabular}

$* * * \mathrm{p}<0.001 * * \mathrm{p}<0.01 * \mathrm{p}<0.05 . \mathrm{p}<0.1$

Open Access This article is licensed under a Creative Commons Attribution 4.0 International License, which permits use, sharing, adaptation, distribution and reproduction in any medium or format, as long as you give appropriate credit to the original author(s) and the source, provide a link to the Creative Commons licence, and indicate if changes were made. The images or other third party material in this article are included in the article's Creative Commons licence, unless indicated otherwise in a credit line to the material. If material is not included in the article's Creative Commons licence and your intended use is not permitted by statutory regulation or exceeds the permitted use, you will need to obtain permission directly from the copyright holder. To view a copy of this licence, visit http://creativecommons.org/licenses/by/4.0/. 


\section{References}

Abernathy WJ, Utterback JM (1975) A dynamic model of process and product innovation. OMEGA, The international Journal of Management Science 3(6):639-656

Abernathy WJ, Utterback JM (1978) Patterns of industrial innovation. Technol Rev 80(7):40-47

Agarwal R, Echambadi R, Sarkar MB (2002) The conditioning effect of time on firm survival: a life cycle approach. Acad Manag J 45(8):971-994

Batlle C, Pérez-Arriaga IJ, Zambrano-Barragán P (2012) Regulatory design for RES-E support mechanisms: learning curves, market structure, and burden-sharing. Energy Policy 41(2012):212-220

Beise M (2004) Lead markets: country-specific drivers of the global diffusion of innovations. Res Policy 33(6-7):997-1018

Beise, M, Rennings, K (2003): Lead markets of environmental innovations: a framework for innovation and environmental economics. ZEW discussion paper no. 03-01, Mannheim

Bento N, Fontes M (2015) The construction of a new technological innovation system in a follower country: wind energy in Portugal. Technological Forecasting and Social Change, Volume 99:197-2010

Bergek A, Jacobsson S (2003) The emergence of a growth industry: a comparative analysis of the German, Dutch and Swedish wind turbine industries. In: Metcalfe JS, Cantner U (eds) Change, transformation and development. Physica, Heidelberg

Bergek A, Jacobsson S (2010) Are tradeable green certificates a cost-efficient policy driving technical change or a rent-generating machine? Lessons from Sweden 2003-2008. Energy Policy 38(2010):1255-1271

Bergek A, Jacobsson S, Carlsson B, Lindmark S, Rickne A (2008) Analyzing the functional dynamics of technological innovation systems: a scheme of analysis. Res Policy 37:407-429

Berkley LAB (2017): Annual U.S. Turbine Installation Capacity by Original Equipment Manufacturer (OEM) 1990-2016. Based on wind technologies market report, personal information from mark Bolinger, Lawrence Berkeley National Laboratory, 21.12.2017

Binz C, Truffer B (2017) Global innovation systems - a conceptual framework for innovation dynamics in transnational contexts. Res Policy 46(2017):1284-1298

BMWi (2018) Time series for the development of renewable energy sources in Germany - based on statistical data from the Working Group on Renewable Energy- Statistics (AGEE-Stat). Federal Ministry for Economic Affairs and Energy, https://www.erneuerbareenergien.de/EE/Navigation/DE/Service/Erneuerbare_Energien in Zahlen/Zeitreihen/zeitreihen.html

BP (2018): Statistical review of world energy. https://www.bp.com/en/global/corporate/energyeconomics/statistical-review-of-world-energy.html

BTM/Navigant (2017): World Wind Energy Market Updates. https://www.navigantresearch. $\mathrm{com} /$ research/world-wind-energy-market-update-2017

Bürer MJ, Wüstenhagen R (2009) Which renewable energy policy is a venture capitalist's best friend? Empirical evidence from a survey of international cleantech inventors. Energy Policy 37(2009):49975006

Carlsson B, Stankiewicz R (1991) On the nature, function and composition of technological systems. Evol Econ 1:93-118

Carlsson B, Jacobsson S, Holmén M, Rickne A (2002) Innovation systems: analytical and methodological issues. Res Policy 31:233-245

Clark KB (1985) The Interaction of Design Hierarchies and Market Concepts in Technological Evolution. Risomb Policy 14:235-251

CWEA (2017): Annual report of China wind power installed capacity statistics (2002-2016). Chinese wind energy association (CWEA)

Danish Energy Agency (2017): Stamdataregister for vindkraftanlæg, ultimo september 2017, https://ens. $\mathrm{dk} /$ service/statistik-data-noegletal-og-kort/data-oversigt-over-energisektoren

Darmani A, Arvidsson N, Hidalgo A, Albors J (2014) What drives the development of renewable energy technologies? Toward a typology for the systemic drivers. Renew Sust Energ Rev 38(2014):834-847

Davies A (1997) The life cycle of a complex product. Int J Innov Manag 1(3):229-256

Dewald U, Truffer B (2011) Market formation in technological innovation systems-diffusion of photovoltaic applications in Germany. Ind Innovation 18:285-300

DEWI (2017) Wind energy use in Germany 1992-2016. Deutsches Windenergie Institut https://industries.ul. com/energy/wind

Dosi G (1982) Technological paradigms and technological trajectories - a suggested interpretation of the determinants and directions of technical change. Res Policy 11(1982):147-162 
Douthwaite B (2002) Enabling innovation - a practical guide to understanding and fostering technological change. Zed Books Ltd.

Durstewitz M, Ensslin C, Hahn B, Hoppe-Klipper M, Rohrig, K (2001) Wind energy report Germany 1999/ 2000. Annual evaluation of WMEP; Windenergie Report Deutschland 1999/2000. Jahresauswertung des WMEP. Germany

Enercon (2018): Historie von Enercon. https://www.enercon.de/unternehmen/historie/

EPI (2018) The great transition: shifting from fossil fuels to solar and wind energy. Earth Policy Institute http://www.earth-policy.org/?/data_center/C23/

Eurec K, Sullivan P, Gleason M, Hettinger D, Heimiller D, Lopez A (2017) An improved global wind resource estimate for integrated assessment models. Energy Econ 64:552-567

Ford D, Ryan C (1981) Taking technology to market. Harv Bus Rev 59:117-126

Freeman C (1995) The ,national system of innovation' in historical perspective. Camb J Econ 19:5-24

GE (2018) Geschichte. GE Renewable Energy https://www.gerenewableenergy.com/de/unternehmen/uber-uns

Giachetti C, Marchi G (2010) Evolution of firms' product strategy over the life cycle of technology-based industries: A case study of the global mobile phone industry, 1980-2009. Bus Hist 52(7):1123-1150

Gipe, P (1995): Wind energy comes of age. John Wiley \& Sons, Inc, ISBN 0-471-10924-X

Gort M, Klepper S (1982) Time Paths in the Diffusion of Product Innovations. Econ J 92(367):630

Groba, F and Breitschopf, B (2013): Impact of renewable energy policy and use on innovation - a literature review. DIW discussion paper, 1318

Grubb M (2004) Technology innovation and climate change policy: an overview of issues and options. Keio Economic Studies 41(2):103-132

GWEC (2018) Global wind report 2006-2017. Global Wind Energy Council http://gwec. net/publications/global-wind-report-2/

Haas R, Panzer C, Resch G, Ragwith M, Reece G, Held A (2011) A historical review of promotion strategies for electricity from renewable energy sources in EU countries. Renewable and Sustainable Energy Review 15(2011):1003-1034

Hekkert M, Suurs RAA, Negro S, Kuhlmann S, Smits R (2007) Functions of innovation systems: a new approach for analysing technological change. Technol Forecasting Soc Change 74:413-432

Hoppe-Killper, M. (2003): Entwicklung der Windenergietechnik in Deutschland und der Einfluss staatlicher Förderpolitik-Technikentwicklung in den 90er Jahren zwischen Markt und Forschungsförderung. Dissertation, university Kassel, 2003

Huenteler J, Schmidt TS, Ossenbrink J, Hoffmann VH (2016) Technology life-cycles in the energy sectortechnological characteristics and the role of deployment for innovation. In: Technological Forecasting and Social Change, Volume 104:2016

IEA (2017) World energy balances (2017 edition). In IEA energy statistics (Beyond 20/20). International Energy Agency, Paris

IEA/IRENA (2018): IEA/IRENA Joint Policies and Measures database. https://www.iea. org/policiesandmeasures/renewableenergy/

IRENA (2012) 30 years of policies for wind energy - lessons from 12 wind energy markets. International Renewable Energy Agency

IRENA (2018): Renewable capacity statistics. International renewable energy agency, march 2018, ISBN: 978-92-9260-05-0

Jacobs D (2014) Policy invention as evolutionary tinkering and codification: the emergence of feed-in tariffs for renewable electricity. Environmental Politics 23(5):755-773

Jacobsson S, Bergek A (2006) A framework for guiding policy-makers intervening in emerging innovation systems in 'catching-up' countries. Eur J Dev Res 18:687-707

Jacobsson S, Johnson A (2000) The diffusion of renewable energy technology: an analytical framework and key issues for research. Energy Policy 28(2000):625-640

Jaeger, A (2013): California: wind farms retrospective. In: Maegaard, P., Krenz, A., Palz, W. (2013): wind power for the world: the rise of modern wind energy. Pan Standford series on renewable energy volume 2, Taylor \& Francis Group, LLC

Jovanovic B, MacDonald GM (1994) The life cycle of a competitive industry. Journal of Political Economy 102:322-347

Karnoe P, Garud R (2012) Path-creation of Heterogeneous Ressources in the Emergence of the Danish Wind Turbine Cluster. European Planning Studies Vol. 20, No. 5, May 2012.Klagge, B., Liu, Z. and Campos Silva, P. (2012): Constructing China's wind energy innovation system. Energy Policy 50(2012):370-382

Kildegaard A (2008) Green certificate markets, the risk of over-investment, and the role of long-term contracts. Energy Policy 36(2008):3413-3421 
Klein, M and Deissenroth, M (2017): When do households invest in solar photovoltaics? - An application of prospect theory. Energy policy, 109, Seiten 270-278

Klepper S (1996) Entry, exit, growth and innovation over theproduct life cycle. Am Econ Rev 86:562-583

Klepper S (1997) Industry life cycles. Ind Corp Chang 6(1):145-182

Klepper S (2002) Firm survival and the evolution of oligopoly. Rand Journal of Economics 33(1):37-61

Klepper S, Graddy E (1990) The evolution of new industries and the determinants of market structure. RAND J Econ 21(1):27-44

Klessmann C, Held A, Rathmann M, Ragwitz M (2011) Status and perspectives of renewable energy policy and deployment in the European Union - what is needed to reach the 2020 targets? Energy Policy 39(2011):7637-7657

Kranzl L, Stadler M, Huber C, Haas R, Ragwitz M, Brakhage A, Gula A, Figorski A (2006) Deriving efficient policy portfolios promoting sustainable energy systems - Case studies applying Invert simulation tool. Renewable Energy 31(15):2393-2410

Lam LT, Branstetter L, Azevedo IML (2017) China's wind industry: leading in deployment, lagging in innovation. Energy Policy 106(2017):588-599

Lee K, Malerba F (2017) Catch-up cycles and changes in industrial leadership: windows of opportunity and responses of firms and countries in the evolution of sectoral systems. Res Policy 46(2017):338-351

Lehmann P, Creutzig F, Ehlers M-H, Friedrichsen N, Heuson C, Hith L, Pietzcker R (2012) Carbon lock-out: advancing renewable energy policy in Europe. Energies 5:323-354

Levitt T (1965) Exploit the product life cycle. Harvard Business Review, November 1965:81-94

Lewis JI (2011) Building a national wind turbine industry: experiences from China, India and South Korea. Int. J. Technology and globalisation 5(3/4):281-305

Lewis J, Wiser RH (2007) Fostering a renewable energy technology industry: an international comparison of wind industry policy support mechanisms. Energy Policy 35(2007):1844-1857

Lund PD (2009) Effects of energy policies on industry expansion in renewable energy. Renewable Energy 34(1):53-64

Lundvall B-A (ed) (1992) National Systems of innovation: towards a theory of innovation and interactive learning. Pinter, London

Lundvall B-A, Johnson B, Andersen ES, Dalum B (2002) National systems of production, innovation and competence building. Res Policy 31(2002):213-231

Maegaard, P, Krenz, A, Palz, W (2013): Wind power for the world: the rise of modern wind energy. Pan Standford series on renewable energy volume 2, Taylor \& Francis Group, LLC

Markard J, Raven R, Truffer B (2012) Sustainability transitions: an emerging field of research and its prospects. Res Policy 41:955-967

Markard J, Hekkert M, Jacobsson S (2015) The technological innovation systems framework: response to six criticisms. Environmental Innovation and Societal Transitions 16(2015):76-86

Menanteau P, Finon D, Lamy M-L (2003) Prices versus quantities: choosing policies for promoting the development of renewable energy. Energy Policy 31(2003):799-812

Menhart M, Pyka A, Ebersberger B, Hanusch H (2004) Product innovation and population dynamics in the German insurance market. Zeitschrift für die gesamte Versicherungswissenschaft 93(3):477-519

Mizuno, E (2007): Cross-border Transfer of Climate Change Mitigation Technologies: The Case of Wind Energy from Denmark and Germany to India. Dissertation, 2007 Massachusetts Institute of Technology

Negro SO, Alkemade F, Hekkert MP (2012) Why does renewable energy diffuse so slowly? A review of innovation system problems. Renew Sust Energ Rev 16(2012):3836-3846

Nemet GF (2009) Demand-pull, technology-push, and government-led incentives for non-incremental technical change. Res Policy 38(2009):700-709

Nordex (2018): 25 years of Nordex - A pionier and trailblazer in the wind industry. https://www.enercon. de/unternehmen/historie/

OECD (2015) Overcoming barriers to International Investment in Clean Energy: local-content requirements in the solar- and wind-energy global value chains. Green Finance and Investment, OECD Publishing, Paris. https://doi.org/10.1787/9789264227064-en

Porter ME (1990) The competitive advantage of nations. Free Press, New York

Quitzow R, Huenteler J, Asmussen H (2017) Development trajectories in China's wind and solar energy industries: how technology-related differences shape the dynamics of industry localization and catching up. J Clean Prod 158(2017):122-133

Sahu BK (2018) Wind energy developments and policies in China: a short review. Renewable and Sustainable Energy Revies 81(2018):1393-1405

Seto KC, Davis SJU, Mitchell RB, Stokes EC, Unruh G, Ürge-Vorsatz D (2016) Carbon lock-in: types, causes, and policy implications. Annu Rev Environ Resour 41:425-452 
Siemens Gamesa (2018): History. https://www.siemensgamesa.com/en-int/about-us/company-history

Stetter, D (2014). Enhancement of the REMix energy system model: global renewable energy potentials, optimized power plant siting and scenario validation

Teske S (ed) (2019) achieving the Paris climate agreement goals - global and regional 100\% renewable energy scenarios with non-energy GHG pathways for $+1.5^{\circ} \mathrm{C}$ and $+2^{\circ} \mathrm{C}$. Springer https://www.springer. com/la/book/9783030058425

The Wind Power (2018) Wind farm database. Status 3:2018 https://www.thewindpower.net/index.php

United Nations (2015): Paris Agreement. http://unfccc.int/paris_agreement/items/9485.php

Unruh GC (2000) Understanding carbon lock-in. Energy Policy 28(2000):817-830

Vernon R (1966) International investment and international trade in the product cycle. Q J Econ 80:190-207

Vernon R (1979) The product cycle hypothesis in the new international environment. Oxf Bull Econ Stat 41: 255-267

Vestas (2018): https://www.vestas.com/en

Vestergaard, J, Brandstrup, L, Goddard, RD (2004): Industry formation and state intervention: the case of the wind turbine industry in Denmark and the United States. Published in the academy of international business (Southeast USA chapter) conference proceedings, November 2004, pp. 329-340

Wang Z, Qin H, Lewis JI (2012) China's wind power industry: policy support, technological achievements, and emerging challenges. Energy Policy 51(2012):80-88

White, W, Lunnan, A, Nybakk, E, Kulisic, B (2013): The role of governments in renewable energy: the importance of policy consistency. Biomass Bioenergy

Wieczorek AJ, Negro SO, Harmsen R, Heimeriks GJ, Luo L, Hekkert MP (2013) A review of the European offshore wind innovation system. Renew Sust Energ Rev 26(2013):294-306

Wiliamson OE (1975) Markets and Hirarchies: analysis and antitrust implications. Free Press, New York

Wind Power Monthly (2017): Top ten turbine makers of 2017. https://www.windpowermonthly. com/article/1445638/top-ten-turbine-makers-2017

Publisher's note Springer Nature remains neutral with regard to jurisdictional claims in published maps and institutional affiliations. 